\title{
Lessons from Drosophila: Engineering Genetic Sexing Strains with Temperature-Sensitive Lethality for Sterile Insect Technique Applications
}

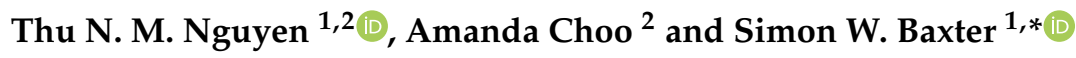 \\ 1 Bio21 Institute, School of BioSciences, University of Melbourne, Melbourne, VIC 3052, Australia; \\ zoey.nguyen@student.unimelb.edu.au \\ 2 School of Biological Sciences, University of Adelaide, Adelaide, SA 5005, Australia; \\ amanda.choo@adelaide.edu.au \\ * Correspondence: simon.baxter@unimelb.edu.au
}

check for updates

Citation: Nguyen, T.N.M.; Choo, A.; Baxter, S.W. Lessons from Drosophila: Engineering Genetic Sexing Strains with Temperature-Sensitive Lethality for Sterile Insect Technique Applications. Insects 2021, 12, 243. https://doi.org/10.3390/ insects12030243

Academic Editors: Kostas Bourtzis and Marc Vreysen

Received: 5 January 2021

Accepted: 9 March 2021

Published: 13 March 2021

Publisher's Note: MDPI stays neutral with regard to jurisdictional claims in published maps and institutional affiliations.

Copyright: (C) 2021 by the authors. Licensee MDPI, Basel, Switzerland. This article is an open access article distributed under the terms and conditions of the Creative Commons Attribution (CC BY) license (https:// creativecommons.org/licenses/by/ $4.0 /)$.
Simple Summary: The sterile insect technique is a pest control strategy used to suppress or eliminate regional populations of insects that pose significant threats to agriculture or human health. The process involves mass-rearing, sterilization and release of male insects who fail to produce viable offspring when they mate with wild females, which leads to a population decline. Females are essential for colony propagation in rearing facilities and their selective removal prior to sterile releases remains an ongoing challenge. Developing genetic sexing strains with conditional temperature sensitive lethal mutations offers one strategy to eliminate female embryos through heat treatment, while males carry a wild type allele translocated to the Y-chromosome (or sex determination locus) to maintain their fitness. Here we review point mutations in Drosophila melanogaster genes that cause temperature sensitive phenotypes with the potential or ability to cause embryonic lethality. Re-engineering these known temperature sensitive mutations in other insects using CRISPR/Cas9 technology presents new opportunities to engineer genetic sexing strains for the sterile insect technique.

Abstract: A major obstacle of sterile insect technique (SIT) programs is the availability of robust sex-separation systems for conditional removal of females. Sterilized male-only releases improve SIT efficiency and cost-effectiveness for agricultural pests, whereas it is critical to remove female disease-vector pests prior to release as they maintain the capacity to transmit disease. Some of the most successful Genetic Sexing Strains (GSS) reared and released for SIT control were developed for Mediterranean fruit fly (Medfly), Ceratitis capitata, and carry a temperature sensitive lethal ( $t s l$ ) mutation that eliminates female but not male embryos when heat treated. The Medfly tsl mutation was generated by random mutagenesis and the genetic mechanism causing this valuable heat sensitive phenotype remains unknown. Conditional temperature sensitive lethal mutations have also been developed using random mutagenesis in the insect model, Drosophila melanogaster, and were used for some of the founding genetic research published in the fields of neuro- and developmental biology. Here we review mutations in select D. melanogaster genes shibire, Notch, RNA polymerase II $215 k D a$, pale, transformer-2, Dsor 1 and CK2 $\alpha$ that cause temperature sensitive phenotypes. Precise introduction of orthologous point mutations in pest insect species with CRISPR/Cas9 genome editing technology holds potential to establish GSSs with embryonic lethality to improve and advance SIT pest control.

Keywords: Drosophila melanogaster; embryo lethality; temperature sensitivity; paralysis; CRISPR/ Cas9 mutagenesis 


\section{Introduction}

\subsection{The Sterile Insect Technique (SIT) and the Challenge of Sex Separation}

The sterile insect technique (SIT) is an area-wide, environmentally friendly and speciesspecific biocontrol method aimed at suppressing or eliminating insect pest populations to reduce damage to crops, livestock or transmission of insect-vectored diseases. The strategy involves mass rearing and sterilization of a holometabolous pest species at the pupal stage with gamma or X-ray radiation, rendering individuals unable to produce viable offspring while maintaining the propensity to mate [1]. Sterility is caused by effects including dominant lethal chromosomal breaks and rearrangements in germ cells, which do not inhibit fertilization but do kill the embryo [2]. Periodic or sustained releases of sterilized males at densities that enable them to outcompete wild males and mate with wild females produces non-viable embryos, leading to population suppression and in some cases, eradication [3]. The SIT strategy helps reduce the use of insecticides, which can have negative environmental consequences such as chemical pollution, kill non-target beneficial organisms and result in development of insecticide resistance in wild populations $[4,5]$. Although SIT has been successfully applied against the New World screwworm [6], various species of fruit flies [7], moth species [8], tsetse flies [9], and mosquitoes [9,10], there are opportunities for optimisation of existing SIT programs or expansion of SIT control programs to include additional insect pest species [11,12]. The logistics of mass-rearing invasive insect pests under factory conditions for intentional release are often complex and involve many factors including strain management to maintain genetic diversity, establishing suitable larval diet for large-scale rearing, sex separation as only males are required for SIT, then effective sterilization through radiation, marking, quality control (e.g., emergence rate and flight ability), handling and distribution to obtain high-quality, cost-effective sterile males [13]. This review will focus on a major challenge facing many SIT control programs: the separation of mass-reared males from unrequired females prior to sterilization and release.

Most SIT programs lack the ability to efficiently separate mass-reared males and females thus rely on mixed-sex sterile releases. Removal of the females prior to release is highly desirable for both financial and practical reasons. Sterilized females classed as agricultural pests have the potential to cause limited damage by 'stinging' fruit with their ovipositor to lay ineffective embryos and this can occasionally lead to fungal, bacterial or viral infections in produce [14,15]. In the case of insect disease vector species, sterilized females might contain the potential to transmit pathogens and need to be removed before releasing. Other advantages of releasing only sterile males include enhancing the ratio of mating between sterile males and wild females [15,16], improving rapid dispersal of sterile males into native populations, and reducing the cost of mass-rearing, handling, and releasing of the insects when females are eliminated at an early developmental stage [17,18]. Insect sterilization requires optimization to achieve complete sterility, while avoiding excessive irradiation levels that may adversely damage somatic cells and impact competitiveness. Male and female insects can require different irradiation doses for sterility $[19,20]$. For example, Bushland [21] explained that doses of 50 gray (Gy) were required for sterilization of female screwworms, and 75 Gy was needed to completely prevent egg production, while a lower dose of $25 \mathrm{~Gy}$ achieved sterilization in males. Therefore, by removing females before sterilisation, the optimal radiation doses for males could be applied to improve their quality, competitiveness and to increase the effectiveness of SIT programs.

SIT has been applied to mosquito species [22-24] and tsetse flies [25] due to the ability to separate males and females using morphological variation and differences in developmental timing. The sex separation methods include mechanical sorting by pupal size for certain mosquito species [22] and removal of females by sorting chilled adults or based on earlier emergence times in tsetse flies [25], however, these strategies are often laborious and not easily scalable for SIT programs. Efficient genetic-based methods for sex separation of insect pest species would therefore improve the efficiency and efficacy of 
current SIT programs, and potentially expand implementation of SIT approaches to other pest species where it is not currently utilized.

\subsection{Removal of Females, from Potential to Possible}

Genetic sexing strains (GSS) have been developed using classical genetic approaches to enable efficient sex separation [26]. Strain development involved selection of beneficial phenotypes from polymorphic populations or through random mutagenesis, and the process has been successful for the Mediterranean fruit fly Ceratitis capitata [26], the Oriental fruit fly Bactrocera dorsalis [27], the melon fly Zeugodacus cucurbitae [28], the Mexican fruit fly Anastrepha ludens [29] and the yellow fever mosquito Aedes aegypti [30,31], among many others. Two principle genetic modifications are required to generate GSSs for insects with $X Y$ sex determination systems: (i) introduction of a recessive mutation that serves as a selectable marker (a visible phenotype and/or conditional lethal effect) and (ii) translocation of a wild type allele onto the male Y-chromosome, or linked to male determining loci of species with homomorphic sex chromosomes [30], to rescue functionality [26]. In the resulting strains, the females are homozygous for the mutation displaying the selectable phenotype, whereas the males are heterozygous and have a wild type phenotype.

Multiple GSSs for the Mediterranean fruit fly (Medfly), C. capitata, have been developed and used extensively in SIT control programs around the world. The initial Medfly GSS relied on a white pupae (wp) mutation, resulting in wild type pigmented male and white female pupae which enabled sex separation using a mechanical seed sorter [32]. This type of selectable marker however has several disadvantages: the larval diet is still required to rear females to pupation, there is up to $5 \%$ female contamination rate after sorting and pupae can be damaged by the sorting process, potentially affecting fly performance [33]. In acknowledgement of these disadvantages, a program to develop an alternative sexing system in the Medfly was initiated in 1981 at the FAO/IAEA Insect Pest Control Laboratory in Seibersdorf, Austria [33]. A suitable Medfly temperature sensitive lethal mutation (tsl) closely linked to $w p$ was isolated by using mutagen ethyl methanesulfonate (EMS) and the first generation of $w p / t s l$ GSS VIENNA-42 was made available in the early 1990s [34,35]. When heat-treating $w p / t s l$ GSS embryos at $34^{\circ} \mathrm{C}$ for $24 \mathrm{~h}$, only the males survive due to the presence of a wild type copy of the tsl-wp genetic region translocated to the $\mathrm{Y}$ chromosome. This is potentially due to a protein product of a tsl gene functioning normally at permissive temperatures, but not at restrictive temperatures. Pupal colour provided a system to confirm the removal of females following high temperature treatment. The Medfly tsl has been highly successful for operational use due to the following properties: (i) removal of female embryos by heat treatment can be easily achieved using simple, accurate and inexpensive methods resulting in significant reduction of the economic costs of rearing irradiation, packaging, transport and release [33], (ii) the tsl mutation has no significant negative impact on the strain at normal rearing temperatures which allows for simple maintenance of the colony, and (iii) females accidentally escaping are unlikely to survive in natural environments because they are susceptible to high temperatures at all development stages [26].

Productivity and stability of Medfly wp/tsl GSSs have been associated with the positions of these causal genes relative to the Y-chromosome translocation breakpoints, and several improved strains had been developed including VIENNA-7, VIENNA-8 (Figure 1) and VIENNA- $8^{\text {D53 }}[17,36,37]$. The stability of a GSS is threatened by rare male genetic recombination events, for example, between the wild type Y-chromosome allele and autosome carrying a mutant allele [26,38]. Recombination can result in autosomes carrying wild type alleles that gradually dilute of the "sexing" character of the strain or produce male sensitive to temperature, which effects colony productivity. Whilst there are many advantages to the Medfly GSS, strain development has taken decades [7] and similar approaches have not produced strains for temperature sensitive sex separation in other pest species. Although the genetic basis of the Medfly tsl mutation is yet to be ascertained [39], a major facilitator superfamily gene mutation was recently found to cause the wp phenotype [40] and 
endeavours to identify alternative temperature sensitive mutations with the potential to generate GSSs for other pest species have been considered [41-44].

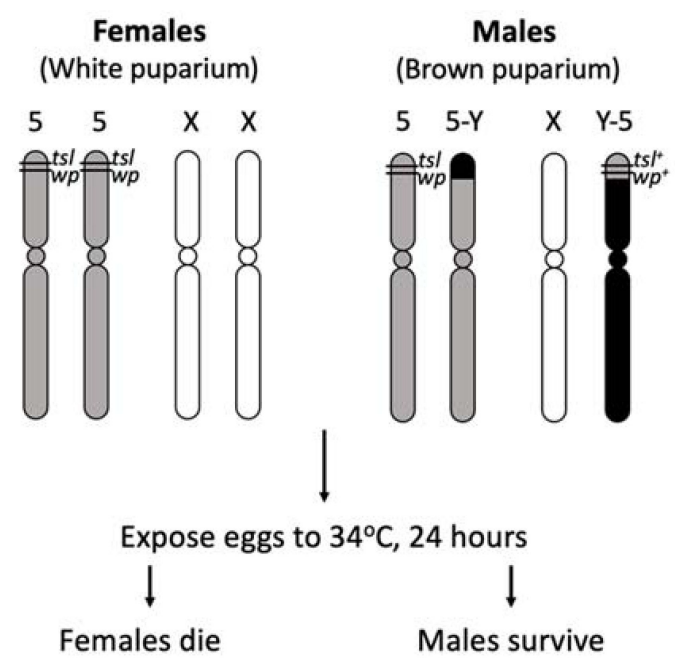

Figure 1. Principle chromosome structure of the Medfly VIENNA-8 GSS strain (Adapted from Franz [26]). Females are homozygous for chromosome 5 temperature sensitive lethal ( $t s l$ ) and white pupae (wp) mutations and can be selectively removed with heat applications at the embryo stage. Females reared at permissive temperatures express a white pupae phenotype. Males have wild type $t s l^{+}$and $w p^{+}$alleles translocated to the $\mathrm{Y}$ chromosome resulting in resistance to temperature selection and a brown puparium.

In addition to strategies involving classical genetics, major efforts have been undertaken to generate transgenic sexing strains (TSSs) through genetic modification. Several transgenic sexing strategies have been developed in the insect model Drosophila melanogaster (D. melanogaster) and the approaches replicated in other insect systems [45-47]. One common strategy involves promoters or enhancers of early-acting cellularization genes driving expression of a tetracycline-repressible transactivator gene (tTA), which in turn, drives expression of a lethal gene that is sex-specifically spliced for activity in female embryos [48-50], or RNAi to target female specific transcripts [51]. Rearing insects on diet containing tetracycline represses the tTA and a 1:1 sex ratio is obtained, whereas the absence of tetracycline results in $\sim 100 \%$ female-lethality and a $50 \%$ hatching rate. The tetracycline-off system effectively removes female, yet adding antibiotic to insect diet creates additional financial costs, can impact insect viability through affecting symbiotic communities and there are environmental implications for waste disposal. Alternate transgenic sexing system have distorted sex ratios through "shredding" meiotic X-chromosomes thus favouring Y-chromosome sperm and the production of male progeny [52]. Other transgenic approaches have introduced fluorescence marker genes onto the $\mathrm{Y}$ chromosome or linked to a male-specific regulatory element, [53-57] allowing separation of transgenic males from females by automated fluorescent sorting. TSSs have multiple beneficial factors associated with them including sharing common transgene components between different insect systems, the opportunity to engineer two or more independent female elimination systems in a single strain to increase efficiency [58] and to trigger lethality or fitness costs at specific life stages [59]. Generation of TSSs requires insertion of foreign DNA from other species into the insect genome, which can result in social and legislative implications regarding their acceptance and adoption [60]. To potentially avoid these issues, Subtractive Transgene Sex Sorting has recently been developed in D. melanogaster as an innovative strategy to mass produce non-transgenic males by crossing specialised stocks of transgenic insects that carry tetracycline repressible lethal circuits on sex chromosomes [61].

Opportunities for developing GSSs where the female carries a conditional lethal allele exist for species with ZZ/ZW sex chromosomes, such as many Lepidoptera, where females are the heterogamic sex (ZW) [62]. Introducing a dominant conditional lethal mutation 
onto the female-specific $\mathrm{W}$ would allow both sexes to survive at permissive conditions, and select for male progeny under restrictive conditions [63]. The feasibility of this approach was demonstrated in the silkworm, Bombyx mori, by the stable insertion of a transgenic marker, EGFP (enhanced green fluorescent protein), into the $\mathrm{W}$ chromosome that could be detected at most female development stages, but not in males [64]. A dominant conditional lethal mutation inserted directly onto the $\mathrm{W}$, for example using the piggyBac transposon [65], or translocation of a dominant gene from the $\mathrm{Z}$ chromosome or autosome to the $\mathrm{W}$, would be required to establish a sexing strain. The development of TSSs was initiated in the codling moth, Cydia pomonella, [66] but low efficiency of transgenesis in this species limited the research progress [8]. Several advantages of developing strains with dominant $\mathrm{W}$ chromosome conditional lethal temperature sensitive mutations include: (i) elimination of females using a restrictive temperature is inexpensive (ii) insect crosses could transfer the $\mathrm{W}$ chromosome (carrying the dominant allele) into a genetic background that best suited a particular country or region (iii) and the released sterile males will not carry transgenic constructs or factors associated with the sexing selecting process [66].

Precise CRISPR/Cas9 genome engineering technology holds the potential to create GSSs through targeted mutagenesis, without requiring insertion of transgenes from foreign species. The CRISPR/Cas9 technology has been successfully established in many insect pest species [67-71] and can therefore be used to introduce tsl mutations into the pest genome as the first step of generating a new GSS. Whilst the genetic nature of the tsl mutation in the Medfly GSS is unknown, temperature sensitive mutations have been identified and characterised in other organisms including the model insect D. melanogaster. Establishing equivalent orthologous mutations in pest insect species using CRISPR/Cas9 has the potential to create temperature sensitive lethal strains that could be developed into GSSs. This would involve identification of suitable candidates among known D. melanogaster temperature sensitive mutations, introducing the orthologous mutation into the genome of the pest species using CRISPR/Cas9, and subsequently, translocation of a dominant wild type allele to the male-specific $\mathrm{Y}$ chromosome to rescue males, or translocation of a dominant mutant allele to the female-specific $\mathrm{W}$ chromosome to cause female conditional lethality.

\section{Lessons from Drosophila melanogaster}

The vinegar fly D. melanogaster was adopted as a research tool more than a century ago and is the model insect for investigating and understanding gene function. In the late 1960s and early 1970s, fundamental research into the developmental and neurobiology of multicellular organisms prompted some of the first studies in D. melanogaster in which temperature sensitive ( $t s)$ mutants were created with EMS mutagenesis [72] to help understand cell fate and regulation of behaviour [73-75]. Homozygous mutants exhibited wild type activity at permissive temperatures and their biological defects were examined through exposure of the insects to high temperatures during specific developmental stages. Temperature sensitive lethal $(t s l)$ factors reported for $D$. melanogaster and other species such as Saccharomyces cerevisiae yeast [76,77], have commonly been shown to be the consequence of a single amino acid substitution in a polypeptide which alters protein activity, function or stability at different temperatures. These tsl mutations may have conserved function in other species, hence are potential candidates for developing GSSs. Of interest are the D. melanogaster tsl mutations that can satisfy three key requirements for developing GSSs: (i) they cause lethality at early development stages when embryos are treated at restrictive temperatures, (ii) females are viable and fecund at standard permissive temperatures for large scale production, and (iii) the mutation must be recessive in insects with $\mathrm{XY} / \mathrm{XX}$ sex chromosomes, so female homozygotes can be efficiently eliminated and males rescued by introducing the wild type allele to the Y chromosome. Species with ZW/ZZ (female/male) sex chromosomes would benefit from dominant mutations that remove females at restrictive temperatures when inserted onto the $\mathrm{W}$ chromosome. The $D$. melanogaster tsl mutations discussed below are listed in Table 1. 
Table 1. Characterised Drosophila melanogaster temperature sensitive mutations with potential to cause embryonic lethality if introduced into other insect species.

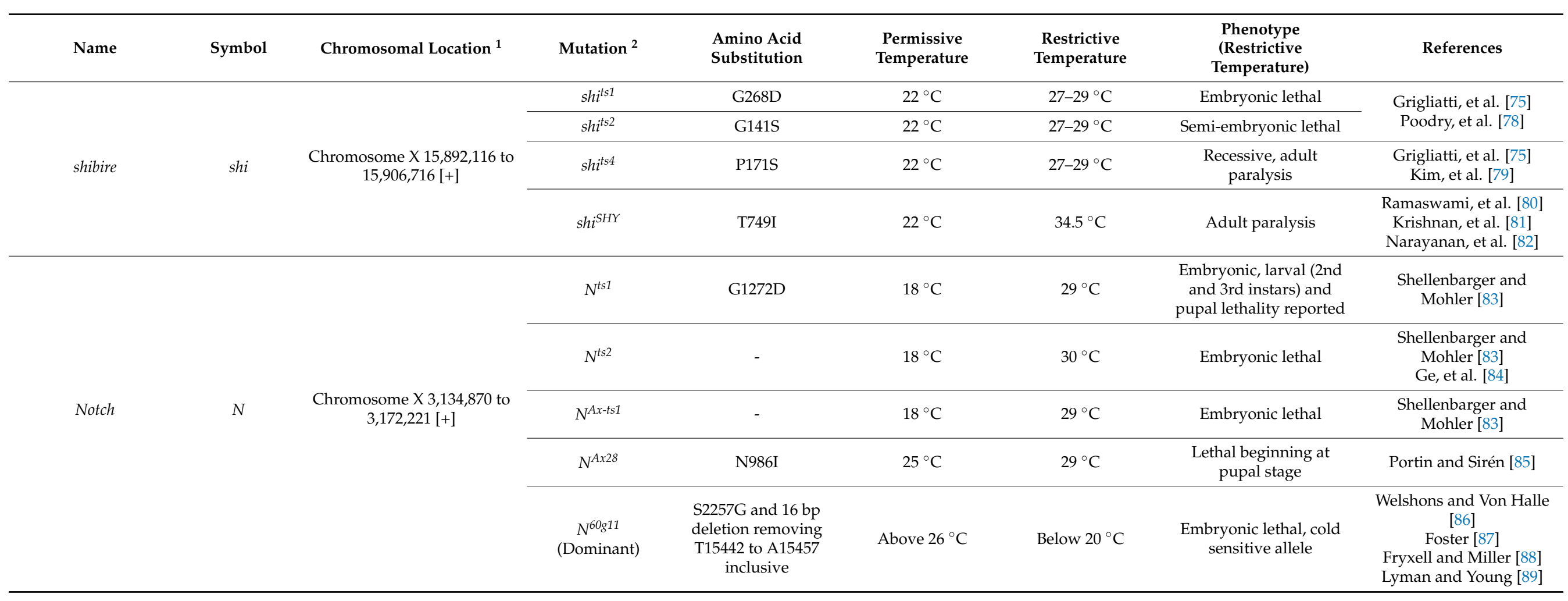


Table 1. Cont.

\begin{tabular}{|c|c|c|c|c|c|c|c|c|}
\hline Name & Symbol & Chromosomal Location $^{1}$ & Mutation $^{2}$ & $\begin{array}{l}\text { Amino Acid } \\
\text { Substitution }\end{array}$ & $\begin{array}{l}\text { Permissive } \\
\text { Temperature }\end{array}$ & $\begin{array}{c}\text { Restrictive } \\
\text { Temperature }\end{array}$ & $\begin{array}{l}\text { Phenotype } \\
\text { (Restrictive } \\
\text { Temperature) }\end{array}$ & References \\
\hline $\begin{array}{l}\text { RNA polymerase II } \\
215 k D \text { subunit }\end{array}$ & RpII215 & $\begin{array}{c}\text { Chromosome X 11,562,800 to } \\
11,570,326[-]\end{array}$ & RpII215 ${ }^{\text {ts }}$ & R977C & $22{ }^{\circ} \mathrm{C}$ & $29^{\circ} \mathrm{C}$ & $\begin{array}{l}\text { Semi-embryonic lethal } \\
\text { and completely lethal if } \\
\text { continue treat at RT until } \\
\text { first instar larvae }\end{array}$ & $\begin{array}{c}\text { Mortin and Kaufman } \\
\text { [90] }\end{array}$ \\
\hline $\begin{array}{l}\text { pale (tyrosine } \\
\text { hydroxylase) }\end{array}$ & ple & $\begin{array}{c}\text { Chromosome 3L 6,713,356 to } \\
6,719,525[-]\end{array}$ & $p l e^{t s 1}$ & C415R & $18^{\circ} \mathrm{C}$ & $29^{\circ} \mathrm{C}$ & Embryonic lethal & Pendleton, et al. [91] \\
\hline \multirow{2}{*}{ transformer-2 } & \multirow{2}{*}{ tra-2 } & \multirow{2}{*}{$\begin{array}{c}\text { Chromosome } 2 \mathrm{R} 14,602,004 \\
\text { to } 14,604,337[-]\end{array}$} & $\operatorname{tra}-2^{t s 1}$ & $\mathrm{~A} 151 \mathrm{~V}$ & - & $16^{\circ} \mathrm{C}, 29^{\circ} \mathrm{C}$ & $\begin{array}{c}\text { Sterility, pseudo XX } \\
\text { males }\end{array}$ & \multirow{2}{*}{ Belote and Lucchesi [92] } \\
\hline & & & $\operatorname{tra}-2^{t s 2}$ & P181S & $16^{\circ} \mathrm{C}$ & $29^{\circ} \mathrm{C}$ & $\begin{array}{l}\text { Sterility, pseudo XX } \\
\text { males }\end{array}$ & \\
\hline Downstream of raf1 & Dsor1 & $\begin{array}{c}\text { Chromosome X 9,247,342 to } \\
9,250,037[+]\end{array}$ & $D-m e k^{t s 1}$ & P209S & $20^{\circ} \mathrm{C}$ & $25^{\circ} \mathrm{C}$ & $\begin{array}{l}\text { Lethal (unreported stage } \\
\text { of development). } \\
\text { Temperature sensitivity } \\
\text { observed during } \\
\text { oogenesis. }\end{array}$ & Hsu and Perrimon [93] \\
\hline
\end{tabular}

\footnotetext{
are recessive unless indicated.
} 


\subsection{Shibire}

Temperature sensitive mutations in the $\mathrm{X}$-chromosomal shibire (shi) locus were first isolated in D. melanogaster by Grigliatti, et al. [75]. Six different ts mutations (designated as $s h i^{t s 1}$ to $s h i^{t s 6}$ ) that resulted in reversible adult paralysis were found by screening through $1.1 \times 10^{6}$ progeny of EMS-mutagenized flies. Three of those mutations $\left(s h i^{t s 1}\right.$, shits ${ }^{t s}$ and $s h i^{t 56}$ ) were also reported to have an embryonic lethal phenotype and larval paralysis at a restrictive temperature of $29^{\circ} \mathrm{C}$ [75]. Shits mutants displayed both larval and adult paralysis whereas $s h i^{t s 4}$ and $s h i^{t s 5}$ flies only showed the adult paralysis phenotype. In 1991, the shibire gene was found to encode D. melanogaster dynamin, a GTPase responsible for endocytosis and vesicle recycling [94,95]. The D. melanogaster shits1, shits2 and shits4 alleles have been reported to each contain a point mutation resulting in a single amino acid substitution (G268D, G141S and P171S, respectively) either at the boundary or within the shibire GTPase domain [95]. The homologous shits1 mutation in human cells as well as a mutation in the C. elegans shibire GTPase domain have also been shown to have a temperature sensitive effect $[96,97]$, indicating that the temperature sensitivity associated with shibire mutations occur in other species. Several other shibire ts mutants have since been reported, however not all identified at the sequence level [80-82,98]. One of these mutations, shi ${ }^{S H Y}$ (T749I), occurs within the GTPase effector domain (GED) and result in adult paralysis at $34.5^{\circ} \mathrm{C}$ [80-82]. The majority of other mutations are dominant and result in complete homozygous lethality, with a paralytic phenotype observed in heterozygous adults [98].

In D. melanogaster, shits1 mutant adults exhibited normal behaviour at a permissive temperature of $22{ }^{\circ} \mathrm{C}$, whereas complete paralysis was observed within 3 min of shifting from $22{ }^{\circ} \mathrm{C}$ to $29^{\circ} \mathrm{C}$ and death after exposure to $29^{\circ} \mathrm{C}$ for $12-14 \mathrm{~h}$ [75], indicating a temperature sensitive effect. Expression of a wild type copy of shibire in the shits ${ }^{t}$ mutant background was able to rescue the adult paralytic phenotype at the tested restrictive temperature of $27^{\circ} \mathrm{C}$, with $t$ s induced paralysis only evident at $30-35^{\circ} \mathrm{C}$ [95]. Prolonged heat treatment of $29^{\circ} \mathrm{C}$ for more than $18 \mathrm{~h}$ at different life stages resulted in complete lethality of homozygous shits1 embryos, larvae, pupae, and adults, which demonstrates that the ts mutants can be killed at higher temperatures $[75,78,99]$. At the permissive temperature of $22{ }^{\circ} \mathrm{C}$, a $77 \%$ egg hatch rate, $54 \%$ larval survival and $98 \%$ prepupae eclosion was observed for homozygous $s h i^{t s 1}$ mutants. In sum, $41 \%$ of $s h i^{\text {ts } 1}$ eggs develop successfully to eclosion under permissive temperatures, suggestive of a fitness cost, however it could not be ruled out that other background mutations, or the effects of inbreeding, may also cause or contribute to high mortality rates [78].

The orthologous shibire gene has been identified in the Queensland fruit fly, Bactrocera tryoni [42], and shares approximately $90 \%$ amino acid conservation with D. melanogaster. CRISPR/Cas9 gene editing was used to introduce an identical shits1 mutation into B. tryoni by substituting a guanine nucleotide with adenine, which altered amino acid 268 from a highly conserved glycine residue to an aspartic acid. Heterozygous shits1 mutants were identified among $G_{1}$ progeny and intercrossed with the aim of obtaining homozygous mutants to test for the effects of temperature sensitivity. Genetic crosses performed at a series of theoretically permissive temperatures (including $21^{\circ} \mathrm{C}$ ) over three generations failed to produce viable $B$. tryoni shits ${ }^{\text {ts }}$ homozygous mutant adults, suggestive of a homozygous lethal effect. A fitness cost associated with a single copy of the $s h i^{t s 1}$ mutant allele was also evident in heterozygotes, even at a low temperature. The observed phenotype associated with the B. tryoni shits1 mutation was more severe than that reported for D. melanogaster, making it unsuitable to be used as a GSS tsl candidate for B. tryoni [42].

The $D$. melanogaster shits ${ }^{\text {ts }}$ mutation has been reported to have a milder phenotype relative to $s h i^{t s 1}[75,78,100]$, with initial reports of only temporary larval and adult paralysis and no embryonic phenotype at $29^{\circ} \mathrm{C}$ [75]. A more detailed examination by Poodry, et al. [78] established that $s h i^{t s 2}$ mutants displayed developmental defects upon heat treatment at $31^{\circ} \mathrm{C}$ and $34^{\circ} \mathrm{C}$ similar to that observed in shits mutants at $29^{\circ} \mathrm{C}$. Shits ${ }^{t s}$ adults became paralysed at lower temperatures and more rapidly than $s h i^{t s 2}$ flies and conversely 
required more time to recover from the paralysis [100]. Although initial reports showed no evidence of the $s h i^{t s 2}$ mutation resulting in embryonic lethality, we have found that heat treatment of $s h i^{t s 2}$ embryos at $29^{\circ} \mathrm{C}$ resulted in lethality of $88 \%$ of embryos compared to $26 \%$ observed for wild type Canton S flies (Figure 2A), indicating that the $s h i^{\text {ts } 2}$ mutation has a moderate effect on $D$. melanogaster embryonic viability. Whilst a low number of $s h t^{i s 2}$ adults had previously been recovered when mutants were maintained at $29^{\circ} \mathrm{C}$ throughout development until prior to eclosion [78], we did not observe any adult survivors when the $29^{\circ} \mathrm{C}$ heat treatment was continually applied until after the expected period of eclosion, even though $s h i^{t s 2}$ flies were viable at $25^{\circ} \mathrm{C}$ (Figure $2 \mathrm{~B}, \mathrm{C}$ ). This was supportive of the $s h i^{i s 2}$ mutation still able to result in lethality upon heat treatment albeit having a less severe effect than the $s h i^{t s 1}$ mutation. Male $s h i^{t s 2}$ mutants carrying a translocated wild type allele on the $\mathrm{Y}$ chromosome were protected from the heat treatment and were found to be viable at the embryonic stage and as adults (Figure 2). This observation demonstrates that the tsl effects of $s h i^{t s 2}$ can be rescued by a wild type shibire allele present on the $\mathrm{Y}$ chromosome, which is an essential criterion of a GSS.

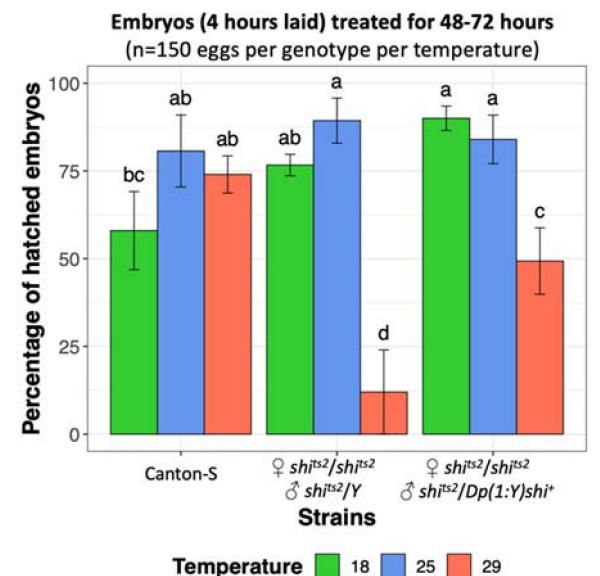

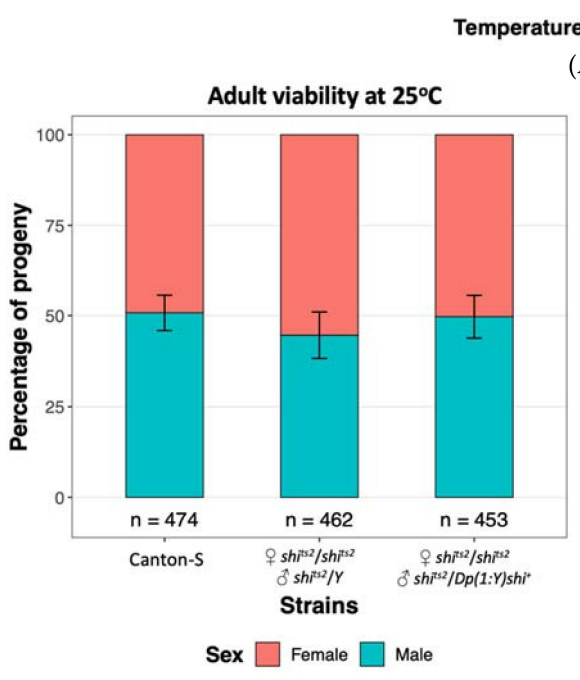

(B)
(A)

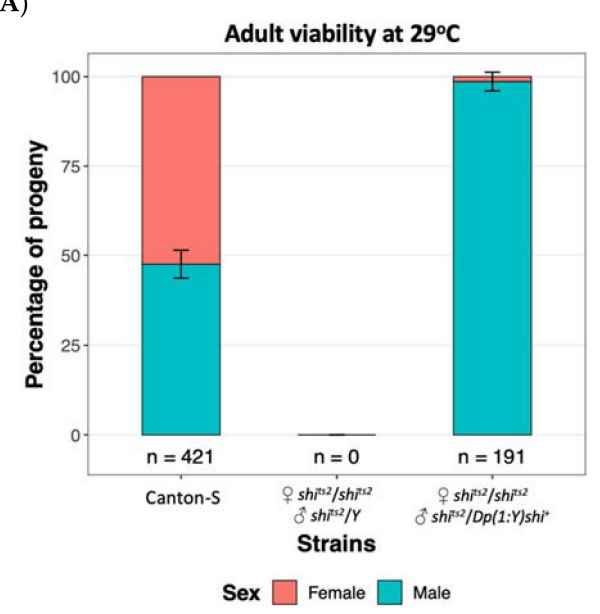

(C)

Figure 2. Embryo survival and fly viability at $18{ }^{\circ} \mathrm{C}, 25^{\circ} \mathrm{C}$ and $29^{\circ} \mathrm{C}$ of Drosophila melanogaster wild type strain Canton-S [Bloomington Stock ID 64349], temperature sensitive shibire strain $s h i^{t s 2}\left(\rho s h i^{t s 2} / s^{t} i^{t s 2}\right.$ and $\left.\sigma^{\top} s h i^{t s 2} / Y\right)$ [Bloomington Stock ID 2248] and shibire Y-chromosome male rescue strain ( $\rho s h i^{t s 2} / s h i^{t s 2}$ and $\sigma^{\top} s h i^{t s 2} / D p(1: Y) s h i^{+}$), generated from crossing shits2 and $D p(1: Y) s h i^{+}$[Bloomington stock ID 4166]. (A) Embryos up to four hours old were collected and maintained at $18{ }^{\circ} \mathrm{C}$, $25^{\circ} \mathrm{C}$ and $29^{\circ} \mathrm{C}$ for $48-72 \mathrm{~h}$. The mean $( \pm \mathrm{SD}$ ) percentage of hatched embryos from three replicates are shown, with 50 eggs per replicate. Significance was assessed using a two-way ANOVA followed by a Tukey post hoc test. The same letter above each bar indicates no significant difference $(p>0.05)$. High embryo mortality rates are observed in the $s h i^{t s 2}$ strain at $29{ }^{\circ} \mathrm{C}$. (B) All strains tested are viable at $25^{\circ} \mathrm{C}$. (C) At $29^{\circ} \mathrm{C}$ no survivorship is observed for the shits 2 strain, unless males carry the Y-chromosome rescue. Data is displayed as a percentage with the total number of flies indicated below each bar. Standard deviations from six to eight replicates are shown (Supplementary Methods S1). 
In addition to the D. melanogaster shits2 mutants, the $s h i^{t s 4}$ and $s h i^{\mathrm{SHY}}$ homozygotes also appear to have milder sensitivity to temperature compared to $s h i^{t s 1}$ homozygotes. $S h i^{t s 4}$ adults take considerably longer to become paralysed at $29^{\circ} \mathrm{C}$ compared to the shits mutants [100] and Grigliatti, et al. [75] reported it as a much weaker paralytic phenotype as the adults were not entirely motionless. The $s h i^{t s 4}$ mutants were also found to be able to recover more quickly from the heat treatment. As for the $s h i^{\mathrm{SHY}}$ homozygotes, they were unaffected at $29^{\circ} \mathrm{C}$ and had a restrictive temperature of $34.5^{\circ} \mathrm{C}$ [81]. Embryonic phenotypes were not reported for either of these mutants and require investigation. The shits1 mutation appears to have some fitness costs in D. melanogaster and was homozygous lethal in B. tryoni. Consequently, the milder $s h i^{t s 2}$, shitst or $s h i^{S H Y}$ mutations may have greater potential as $t s l$ candidates for generating stable GSSs.

\subsection{Notch}

The Notch $(N)$ gene was cloned and sequenced in the mid-1980s, and was found to encode for a large, single heterodimeric transmembrane receptor [101,102]. The Notch protein mediates short-range signalling events and plays critical roles in cell-fate decisions both during embryonic development and in adult tissue homeostasis [103-106].

\subsubsection{Recessive Temperature Sensitive Lethal Notch Mutations}

Shellenbarger and Mohler [107] isolated three recessive $t s l$ alleles $N^{t s 1}, N^{t s 2}$ and $N^{A x-t s 1}$ of the X-linked Notch locus by screening fly lines treated with the mutagen EMS. These Notch tsl alleles have a common lethal defect in embryonic development at restrictive temperatures above $29^{\circ} \mathrm{C}$ [107]. At $18{ }^{\circ} \mathrm{C}$, survival of homozygous $N^{t s 1}$ and $N^{t s 2}$ are $96 \%$ and $90 \%$, respectively, whereas the survival of homozygous $N^{A x-t s 1}$ is considerably lower at only 44\% [107]. Portin and Sirén [85] discovered another Notch recessive tsl allele, $N^{A x 28}$ induced by EMS. When reared at $25^{\circ} \mathrm{C}$, viability of homozygous and hemizygous $N^{A x 28}$ flies were similar to controls, whereas at $29{ }^{\circ} \mathrm{C}$, survivorship was only $6.9 \%$. The temperature sensitive period for $N^{A x 28}$ occurred the beginning of the pupal stage [85]. Both $N^{A x-t s 1}$ and $N^{A x 28}$ exhibit interrupted wing vein phenotypes at permissive and restrictive temperatures, and parallel mutations in other insect species could potentially induce similar visible traits $[107,108]$.

The $N^{t s 1}$ and $N^{A x 28}$ mutations are both single base substitutions resulting in amino acid replacements G1272D within the 32nd epidermal growth factor (EGF)-like repeat motif [109], and N986I in the 25nd EGF-like repeat motif [110], respectively. The EGFlike repeats are primary regions responsible for the interaction of Notch protein and extracellular ligands [111]. The $N^{t s 2}$ and $N^{A x-t s 1}$ mutations have not been reported, however, D. melanogaster stocks are available (Bloomington stock ID 3075 and 3092, respectively).

Treating D. melanogaster homozygous and hemizygous $N^{t s 1}$ embryos continuously at $29{ }^{\circ} \mathrm{C}$ resulted in $30 \%$ hatching rate, however, none of the hatched eggs successfully pupated even were shifted to $18{ }^{\circ} \mathrm{C}$ after hatching. Temperature sensitive periods for lethality of $N^{t s 1}$ were localised to the first half of the embryonic period, the second and third larval instar, and to a 15-h period immediately after pupation [83].Translocation of a short $\mathrm{X}$ chromosome fragment carrying a wild type allele of Notch to the $\mathrm{Y}$ chromosome was able to rescue all defects of $N^{t s 1}$ in males, including the temperature sensitive lethality at $29^{\circ} \mathrm{C}$ [83].

We reassessed adult viability of $N^{t s 1}$ (Bloomington stock ID 2533), relative to control strain $w^{1118}$ (Bloomington stock ID 51629). Six replicate vials of 21 virgin flies (14 females and 7 males) were established at $25^{\circ} \mathrm{C}$ for each strain and eggs were laid for $24 \mathrm{~h}$. Flies were then removed and vials transferred to $18{ }^{\circ} \mathrm{C}$ or $25^{\circ} \mathrm{C}$ until the progeny eclosed. The ratio of male and female progeny was expected to be relatively equal, as rearing temperatures were less than $29^{\circ} \mathrm{C}$, however, the sex ratio of $N^{t s 1}$ flies deviated from expected at both temperatures. Male survivorship at $18{ }^{\circ} \mathrm{C}$ and $25^{\circ} \mathrm{C}$ for $N^{t s 1}$ were $36.7 \%(220 / 599)$ and $3.3 \%(8 / 243)$, respectively, whereas they were $48.4 \%$ (443/915) and $48.2 \%(462 / 959)$ for the control strain. This result highlights a strong fitness cost in males of this particular 
$N^{t s 1}$ stock, and temperature sensitive assays comparing Notch wild type and $N^{t s 1}$ alleles in the same genetic background would be useful in determining if this specific mutation is a suitable candidate for developing GSSs.

\subsubsection{Dominant Temperature Sensitive Lethal Notch Mutations}

The $\mathrm{N}^{60811}$ allele was first reported by Welshons and Von Halle [86] as a dominant temperature sensitive mutation that caused a rough eye abnormality. Foster and Suzuki [112] used temperature shift experiments $\left(21^{\circ} \mathrm{C}\right.$ to $29^{\circ} \mathrm{C}$ and the reverse) to show that $N^{60 g 11}$ heterozygous females were cold sensitive during the third larval instar, which caused eye facet arrangement errors and wing nicking phenotypes. Homozygous females carrying a duplication of wild type $N$ in the 2 nd chromosome $\left(N^{60811} / N^{60 g 11} ; D p(1 ; 2) 51 b\right)$ were viable when reared at $28-29{ }^{\circ} \mathrm{C}$, whereas survival dropped to less that $3 \%$ at $20-22{ }^{\circ} \mathrm{C}$, and the lethality was determined to occur during embryo development [87]. Fryxell and Miller [88] showed that at $26^{\circ} \mathrm{C}$, homozygous $N^{60 g 11} / N^{60 g 11} ; D p(1 ; 2) 51 b$ females and $N^{60 g 11} / Y ; D p(1 ; 2) 51 b$ males had normal viability and mating success, even in competition with a wild type insect population, and rearing males at $18^{\circ} \mathrm{C}$ caused lethality, indicating this $N^{60811}$ phenotype was dominant over two wild type $N$ alleles.

Two alterations were found in the $N^{60 g 11}$ allele [89]. The first was an amino acid substitution at codon 2257, changing a serine to glycine, which had also been reported in several other Notch alleles and indicated that it was not the causal variant associated with this dominant phenotype [110]. The second change was a $16 \mathrm{bp}$ deletion from T15442 to A15457 inclusive, removing 5 amino acids (V2123-R2127) and introducing a frameshift resulting in translation of 19 different amino acids before termination of the protein [89]. The deletion affected cdc10-repeats, resulting in the removal of most of the Notch intracellular domain. Thus, $N^{60 g 11}$ is dominant and sensitive to cold temperature, which could be suited for genetic sexing in $\mathrm{ZW} / \mathrm{ZZ}$ insects, if this allele can be inserted and effectively expressed on the female $\mathrm{W}$ chromosome [66].

\subsection{RpII215}

Mortin and Kaufman [113] discovered a recessive temperature sensitive mutation in the X-linked RpII gene encoding a subunit of RNA polymerase II which is a multisubunit enzyme involved in catalysing the transcription of various types of RNA. The tsl mutation was found to affect the largest subunit that contains a molecular mass of 215,000 Daltons [114]. The single base mutation results in an amino acid substitution at codon 977 changing an arginine residue to cysteine [115], in domain 6 which forms part of the shelf module $[116,117]$. RpII215 ${ }^{t s}$ mutant flies were reported viable and fertile at the permissive temperature of $22^{\circ} \mathrm{C}$, whereas shifting of the embryos to $29^{\circ} \mathrm{C}$ for $48 \mathrm{~h}$ caused lethality at late embryo or first instar larval stages $[90,113]$. Adults RpII215 ${ }^{\text {ts }}$ are viable if maintained at $29^{\circ} \mathrm{C}$, but the females and a proportion of the males become sterile $[90,113]$.

To determine if the RpII215 $5^{t s}$ strain could be reared at temperatures higher than $22{ }^{\circ} \mathrm{C}$ without fitness costs, we assessed embryo hatch rates and performed fly viability assays. There were no significant differences in hatch rates between $R p I I 215^{t s}$ mutants and $w^{1118}$ control embryos at the previously reported permissive temperature of $22^{\circ} \mathrm{C}$, or when reared at $25^{\circ} \mathrm{C}$ (Figure $3 \mathrm{~A}$ ). Similarly, the viability of adult mutants was unaffected at both $22{ }^{\circ} \mathrm{C}$ and $25{ }^{\circ} \mathrm{C}$ (Figure $3 \mathrm{~B}, \mathrm{C}$ ), indicating that $25^{\circ} \mathrm{C}$ is also a suitable permissive temperature for rearing Drosophila RpII215 ts mutants. At the restrictive temperature of $29^{\circ} \mathrm{C}$, approximately $10 \%$ of RpII215 ${ }^{\text {ts }}$ embryos were able to survive the heat treatment (Figure $3 \mathrm{~A}$ ); however when the mutants were continually maintained at this high temperature throughout larval development, it resulted in complete mortality and no pupae were observed, as seen in the finding of Mortin and Kaufman [113]. Homozygous female and hemizygous male mutants failed to eclose at $29^{\circ} \mathrm{C}$, whilst heterozygous mutant females were viable, confirming that the temperature sensitive lethal phenotype for RpII215 ts is recessive (Figure 3D). 


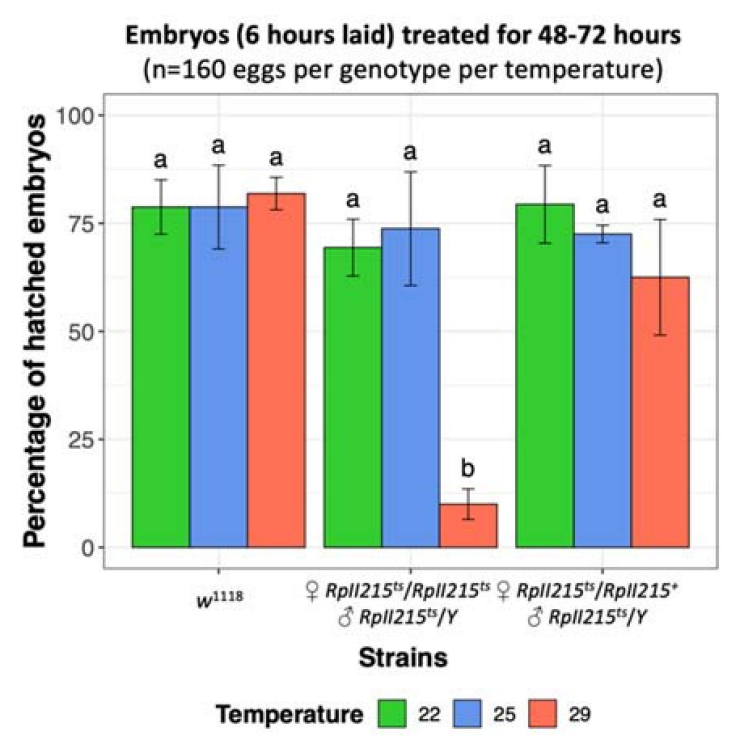

(A)

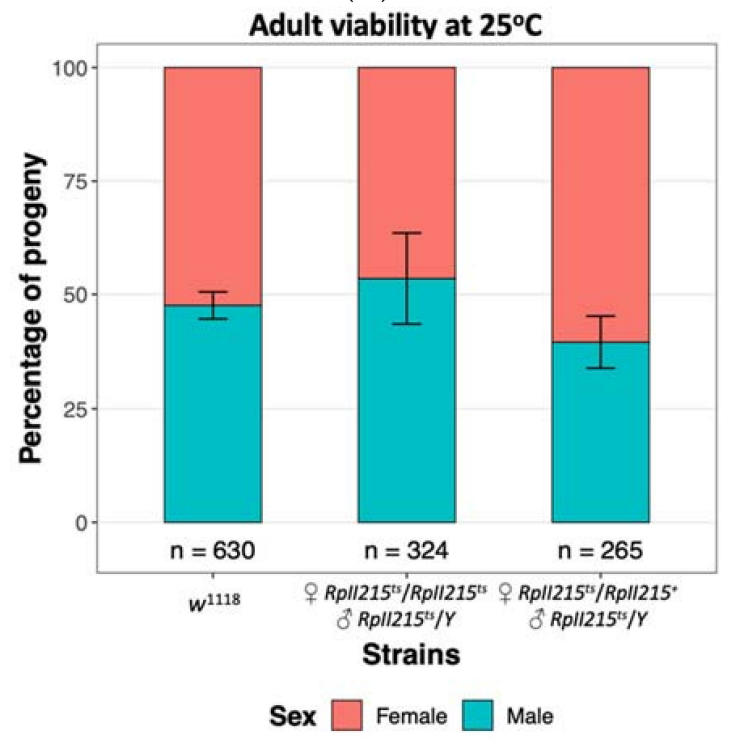

(C)

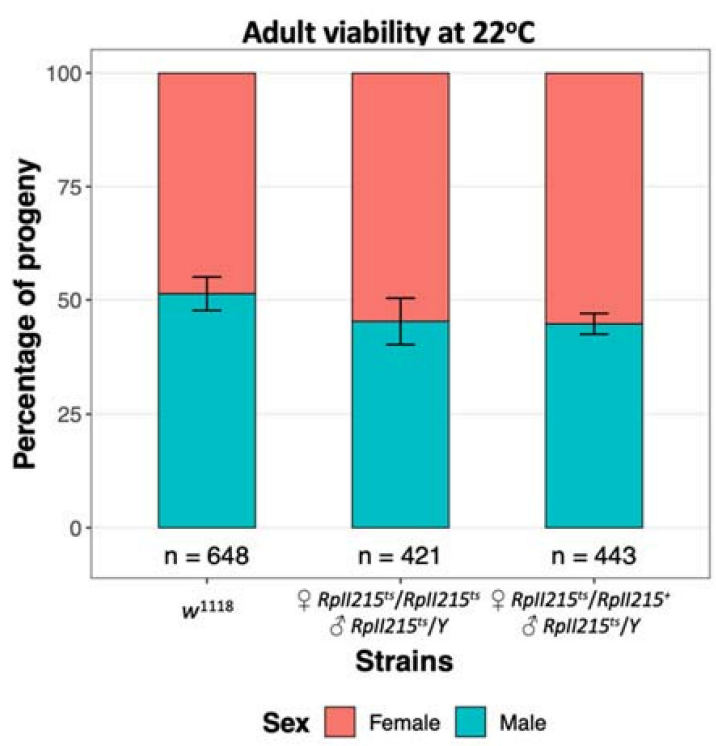

(B)

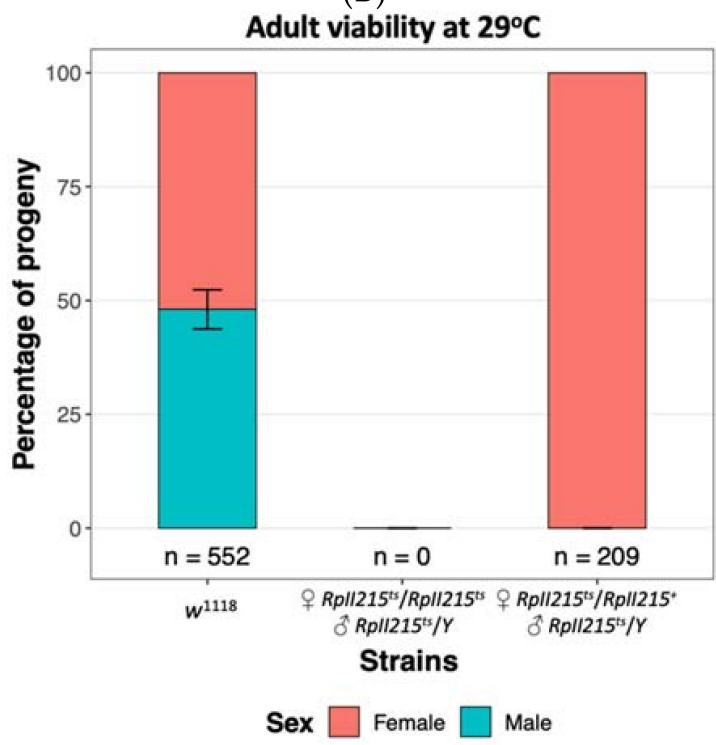

(D)

Figure 3. Embryo survival and fly viability at $22{ }^{\circ} \mathrm{C}, 25{ }^{\circ} \mathrm{C}$ and $29{ }^{\circ} \mathrm{C}$ of Drosophila melanogaster control strain $w^{1118}$

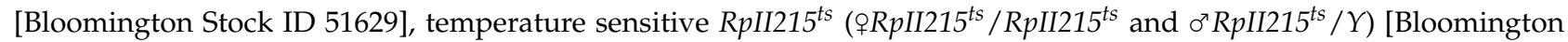
Stock ID 34755] and their hybrid progeny ( $R p I I 215^{t s} / R p I I 215^{+}$and $o^{t} R p I I 215^{t s} / Y$ ). (A) Embryos up to six hours old were collected and maintained at three temperatures for 48-72 h. The mean ( \pm SD) percentage of hatched embryos from four replicate are shown, with 40 eggs per replicate. Significance was assessed using a two-way ANOVA followed by a Tukey post hoc test. The same letter above each bar indicates no significant difference $(p>0.05)$. Observed female and male fly viability at (B) $22{ }^{\circ} \mathrm{C},(\mathbf{C}) 25^{\circ} \mathrm{C}$ and (D) $29^{\circ} \mathrm{C}$ temperatures confirmed rearing at $29^{\circ} \mathrm{C}$ is lethal for homozygous females and hemizygous males, but not heterozygous females. Data is displayed as a percentage with the total number of flies indicated below each bar. Standard deviations from six replicates are shown (Supplementary Methods S1).

\subsection{Pale}

Pendleton, et al. [91] developed a recessive temperature sensitive mutation in the D. melanogaster pale ( $p l e)$ gene with EMS mutagenesis. The ple gene is located on chromosome 3 and encodes an initial rate-limiting enzyme, tyrosine hydroxylase, which is involved in the biosynthesis of 3,4-dihydroxyphenylalanine (DOPA) and dopamine [118]. Previous research has shown that tyrosine hydroxylase plays an essential role in modulating a wide range of behaviour include sleep, locomotion, courtship and learning as well as being the precursor for black melanin synthesis $[118,119]$. The $p l e^{t s}$ allele is a substitution of cysteine 
for arginine at codon 415 . Hemizygous $p l e^{\text {ts } 1} /$ ple-deficiency mutants reared throughout development at $29^{\circ} \mathrm{C}$ showed almost complete lethality, had intermediate viability at $25^{\circ} \mathrm{C}$, and were viable at $18^{\circ} \mathrm{C}$ [91]. Hemizygous and homozygous ple $e^{t s 1}$ mutant adults had normal locomotor activity at $18{ }^{\circ} \mathrm{C}$, but it was significantly reduced when shifted to $25^{\circ} \mathrm{C}$ and $29^{\circ} \mathrm{C}$, suggesting elevated temperatures impair enzyme function. Supplementing adult food medium with L-dopa $(3 \mathrm{mM})$ successfully reversed this behavioural phenotype and restored activity to control levels [91]. Liu, et al. [120] were able to rear homozygous $p l e^{t s 1}$ flies at $25^{\circ} \mathrm{C}$, and noted that males developed notably lighter body pigmentation when moved to restrictive $31^{\circ} \mathrm{C}$ temperatures after eclosion.

Pendleton, et al. [91] writes that "temperature sensitive loss of function mutant alleles of ple are recessive embryonic lethals" and therefore hold potential for creating orthologous conditional tsl mutations for establishing genetic sexing strains among other insect species. While homozygous pale knock-outs are known to be embryonic lethal [118,121], and Pendleton, et al. [91] explains $p l e^{t s 1} / p l e^{t s 1}$ are also embryonic lethal at elevated temperatures, this evidence is based on counting flies that completed development rather than direct assessment of embryo survivorship at $29^{\circ} \mathrm{C}$. Confirming $p l e^{t s 1}$ homozygous embryos fail to hatch at restrictive temperatures would be useful to confirm death does indeed occur at this developmental stage and not as larvae or pupae. The ability to restore wild type locomotor behaviour to $p l e^{t s 1}$ homozygotes using dietary supplements of L-dopa may present useful opportunities to improve fitness of GSS for colony maintenance.

\subsection{Transformer-2}

Mechanisms for initiating sex determination among insects are diverse and can evolve rapidly [122]. Feminisation requires expression of transformer and transformer-2 proteins [123] to enable female specific splicing of doublesex pre-mRNA transcripts [124-126] in $D$. melanogaster and many insect species. RNAi knockdown of tra-2 during early embryogenesis in several tephritid species, including B. dorsalis [127], Bactrocera tau [128], C. capitata [129] and Anastrepha suspensa [130], causes female to male sex conversion. Conditional conversion of XX females to males would potentially benefit SIT by doubling the number of male progeny produced from the parental population, provided all XX pseudomales display wild type mating behaviour and the strain can be effectively propagated under permissive conditions.

Chemical mutagenesis using EMS in D. melanogaster generated two temperature sensitive alleles of transformer-2 (tra- $2^{t s 1}$ and $\left.t r a-2^{t s 2}\right)$ which played an important role in demonstrating that tra-2 expression was required throughout development to complete correct anatomical morphology and for fertility $[131,132]$. At $16^{\circ} \mathrm{C}$, both homozygous mutants produced normal male and female phenotypes, yet the two temperature sensitive alleles did show different severity among their phenotypes. At $16{ }^{\circ} \mathrm{C} t r a-2^{t s 1}$ flies were sterile and tra- $2^{t s 2}$ fertile, and constant rearing at $18^{\circ} \mathrm{C}$ also caused sterility in tra-2 ${ }^{t s 2}$ homozygotes. Increasing rearing conditions to $29^{\circ} \mathrm{C}$ appeared to cause structural instability of both $t r a-2^{t s 1}$ and $t r a-2^{t s 2}$ protein. For example, temperature shift experiments that involved transferring homozygous tra- $2^{\text {ts } 1}$ females from $16^{\circ} \mathrm{C}$ to $29^{\circ} \mathrm{C}$ twelve hours after puparium formation, caused sex-combs to develop with male morphology [131]. Shifting pupae from $29{ }^{\circ} \mathrm{C}$ to $16{ }^{\circ} \mathrm{C}$ resulted in female sex-comb morphology but male bristle number. Nevertheless, rearing XX females at $29^{\circ} \mathrm{C}$ produced flies with intersex or pseudomale phenotypes [133]. Expression of tra-2 indirectly regulates Yolk protein $(Y p)$ synthesis in female D. melanogaster [134], and instability of the protein may affect fertility.

Non-synonymous point-mutations were responsible for these two temperature sensitive alleles; $t r a-2^{t s 1}$ was caused by an alanine to valine substitution (GCC > GTC) at amino acid 151, and tra-2 $2^{\text {ts } 2}$ caused by a proline to serine substitution (CCA > TCA) in at amino acid 181 [133]. Although the tra-2 ${ }^{\text {ts1 }}$ allele substituted similar hydrophobic amino acids, the phenotype was severe and causes sterility when reared at $16^{\circ} \mathrm{C}$ [133]. The wild type alanine residue was highly conserved and is potentially part of the ribonucleoprotein binding motif that interacts with pre-mRNA to affect splicing [135]. As the tra-2 ${ }^{t s 2}$ mutant 
was viable at $16{ }^{\circ} \mathrm{C}$ in $D$. melanogaster and completely sterile at $29{ }^{\circ} \mathrm{C}$, in addition to the reversion of XX-females to incomplete or pseudo-males, it was presented as a candidate temperature sensitive allele to test among other insects for the purpose of developing strains for SIT.

The tra- $2^{t s 2}$ mutation (P181S) was established in both the spotted winged Drosophila suzukii [43] and C. capitata [41] using CRISPR/Cas9 homology directed repair, with the intention of creating strains sensitive to high temperatures, potentially with female to male sex reversion. In $D$. suzukii, fertile tra- $2^{t s 2}$ males could be reared at $24{ }^{\circ} \mathrm{C}$ without dysmorphic testes and fertile females reared at $20^{\circ} \mathrm{C}$, which was a higher permissive temperature than $D$. melanogaster with the equivalent mutation. Despite this promising finding, the tra- $2^{t s 2}$ strain and control strain failed to develop at $29^{\circ} \mathrm{C}$, and when reared at lower temperatures and shifted to $29^{\circ} \mathrm{C}$, the males did not attempt courtship or mating. Temperature sensitive mutants were difficult to rear above $26{ }^{\circ} \mathrm{C}$, yet the D. suzukii tra-2 $2^{\text {ts }}$ phenotype did show useful characteristics at this temperature. The XY males were sterile and expected to be competitive against wild males to mate with wild females, and XX females developed as incomplete pseudo-males that were sterile. The competitive ability for $X X$ intersex individuals to mate with wild females remains unclear. Nevertheless, the lack of an ovipositor would be a major benefit of pseudo-male phenotype as they are unable to damage host plant fruits.

Aumann, et al. [41] successfully produced a tra-2 ${ }^{t s 2} \mathrm{C}$. capitata strain capable of female to male sex conversion at elevated temperatures. However, successful culturing of $C$. capitata is dependent upon rearing temperature, as wild type laboratory strains fail to produce progeny at $16{ }^{\circ} \mathrm{C}$ and production is reduced by $99 \%$ at $18{ }^{\circ} \mathrm{C}$ [41]. The use of transformer-2 temperature sensitive mutations for creating genetic sexing strains may therefore be challenging in some insect species.

\subsection{Dsor1}

The gene Downstream of raf1 (Dsor1, also known as D-mek [93]) is located on the Drosophila X chromosome and encodes a 393 (isoform-B) or 396 (isoform-A) amino acid serine/threonine protein kinase that plays a role in the Torso receptor tyrosine kinase signaling pathway [136]. The Dsor1 gene is expressed throughout development and lossof-function mutation Dsor $1^{\text {LH110 }}$ causes zygotic lethality [136]. Hsu and Perrimon [93] used P-element mediated transformation to develop D. melanogaster strains with Dsor1 non-symonymous substitutions based on known recessive temperature sensitive point mutations in the serine/threonine kinase gene cyclin-dependent protein kinase $c d c 2$ of fission yeast, Schizosacchaiomyces pombe. Although Dsor1 and cdc2 are not orthologs, substituting a conserved proline residue at amino acid 137 in cdc2 and 209 in Dsor1 (isoform-B) for a serine residue was sufficient to cause temperature sensitive phenotypes $[93,137]$. Male flies carrying the Dsor $1^{t s 1}$ allele (referred to as $D-m e k^{t s 1-6}$ by Hsu and Perrimon [93]) in the null lethal Dsor ${ }^{\mathrm{LH} H 10}$ background could develop and were viable at both $18{ }^{\circ} \mathrm{C}$ and $20^{\circ} \mathrm{C}$ (male genotype Dsor $1^{L H 110} / Y$; Dsor $1^{t s 1} /+$ ) but did not survive when continuously reared at $25{ }^{\circ} \mathrm{C}$ [93].

The Dsor $1^{t s 1}$ mutation caused a range of developmental phenotypes at different temperatures. For example, the egg chorion of Dsor $1^{\text {ts } 1}$ embryos laid at $18{ }^{\circ} \mathrm{C}$ show a weakly ventralised eggshell with fused normal length dorsal appendages, which fused and shortened at $25^{\circ} \mathrm{C}$, and reduced to knob like structures at $29^{\circ} \mathrm{C}$ [93]. Dsor $1^{\text {ts } 1}$ larvae exposed to intermittent or continuous elevated temperatures between $20^{\circ} \mathrm{C}$ and $25{ }^{\circ} \mathrm{C}$ also developed a range of rough-eye phenotypes [93]. Hsu and Perrimon [93] demonstrated the Dsor $1^{\text {ts } 1}$ mutation produces a recessive temperature sensitive lethal phenotype above $25^{\circ} \mathrm{C}$. Although the precise developmental stage at which temperature sensitive lethality occurs, the mutation shows potential to be integrated into a GSS. 


\subsection{CK $2 \alpha$}

Casein kinase 2 (CK2) is a highly conserved eukaryotic protein kinase involved in several processes essential for cellular developmental, including cell cycle regulation, cell signalling and embryogenesis, and is comprised of catalytic (CK2 $\alpha)$ and regulatory (CK2 $\beta$ ) subunits [138]. Recessive temperature sensitive mutations were developed in the Saccharomyces cerevisiae ck $\alpha 2$ gene via hydroxylamine mutagenesis, with mutants exhibiting loss-of-function phenotypes including cell cycle arrest at restrictive temperatures above $33^{\circ} \mathrm{C}$ [76]. Five $c k \alpha 2$ temperature sensitive alleles were generated, four of which carried two separate amino acid substitutions, whilst the fifth mutant (cka2-13) had one amino acid replacement due to a single base change (Table 2). Amongst the seven different amino acid residues that were affected, substitutions at positions A190 and D225 occurred in two separate temperature sensitive alleles. These sites are invariant in humans, Xenopus and Drosophila CK2 proteins, as well as other protein kinases [76,77].

Table 2. Saccharomyces cerevisiae ck $2 \alpha$ temperature sensitive alleles and Drosophila melanogaster $d C K 2 \alpha$ transgenes with temperature sensitive phenotypes in yeast.

\begin{tabular}{|c|c|c|c|c|}
\hline \multicolumn{3}{|c|}{$\begin{array}{c}\text { Saccharomyces cerevisiae } \\
\text { Hanna, et al. }[76]\end{array}$} & \multicolumn{2}{|c|}{$\begin{array}{l}\text { Drosophila melanogaster } \\
\text { Kuntamalla, et al. [77] }\end{array}$} \\
\hline $\begin{array}{c}\text { Temperature sensitive } \\
\text { Allele }\end{array}$ & $\begin{array}{l}\text { Amino Acid } \\
\text { Substitution }\end{array}$ & $\begin{array}{l}\text { Nucleotide } \\
\text { Substitution }\end{array}$ & $\begin{array}{c}\text { Temperature sensitive } \\
\text { Allele }\end{array}$ & $\begin{array}{l}\text { Amino Acid } \\
\text { Substitution }\end{array}$ \\
\hline$c k \alpha 2-7$ & $\begin{array}{l}\text { A190T } \\
\text { T336M }\end{array}$ & $\begin{aligned} \mathrm{GCG} & \rightarrow \mathrm{ACG} \\
\mathrm{ACG} & \rightarrow \mathrm{ATG}\end{aligned}$ & YKP7 & A177T \\
\hline$c k \alpha 2-8$ & $\begin{array}{c}\text { E51K } \\
\text { G102D }\end{array}$ & $\begin{array}{l}\mathrm{GAA} \rightarrow \mathrm{AAA} \\
\mathrm{GGC} \rightarrow \mathrm{GAC}\end{array}$ & YKP10 & G89D \\
\hline$c k \alpha 2-11$ & $\begin{array}{l}\text { D225N } \\
\text { E299K }\end{array}$ & $\begin{array}{l}\mathrm{GAC} \rightarrow \mathrm{AAC} \\
\mathrm{GAG} \rightarrow \mathrm{AAG}\end{array}$ & & \\
\hline$c k \alpha 2-12$ & $\begin{array}{l}\text { A190V } \\
\text { H294Y }\end{array}$ & $\begin{array}{l}\mathrm{GCG} \rightarrow \mathrm{GTG} \\
\mathrm{CAC} \rightarrow \mathrm{TAC}\end{array}$ & YKP8 & A177V \\
\hline$c k \alpha 2-13$ & $\mathrm{D} 225 \mathrm{~N}$ & $\mathrm{GAC} \rightarrow \mathrm{AAC}$ & YKP9 & $\mathrm{D} 212 \mathrm{~N}$ \\
\hline
\end{tabular}

Drosophila CK2 $\alpha$ temperature sensitive mutant flies have not been reported, however, the mutations corresponding to several $S$. cerevisiae temperature sensitive alleles have been engineered into $D$. melanogaster $C K 2 \alpha(d C K 2 \alpha)$ transgenes and transformed into yeast for complementation experiments [77]. The wildtype $d C K 2 \alpha$ can rescue the yeast $c k \alpha 2$ loss-offunction mutant phenotype, demonstrating that the D. melanogaster ortholog shares similar function to the yeast. Four different $d C K 2 \alpha$ constructs, each encoding a single amino acid substitution (YKP7-10, Table 2) were then tested and found to rescue the yeast $c k \alpha 2$ lossof-function mutant at permissive temperatures $\left(29^{\circ} \mathrm{C}\right)$ but not at restrictive temperatures $\left(37^{\circ} \mathrm{C}\right)$. Although efficacy varied, robust rescue at permissive temperatures and complete temperature sensitive growth arrest at restrictive temperatures was confirmed for two $d C K 2 \alpha$ alleles, YKP7 (A177T mutation) and YKP9 (D212N mutation) [77]. Expression of the YKP8 allele resulted in incomplete rescue at the permissive temperature, which suggested that the A177V mutation has a negative effect on CK2 $\alpha$ function even at lower temperatures, whilst YKP10 (G89D mutation) was a weak temperature sensitive variant as it displayed incomplete growth arrest at a $37^{\circ} \mathrm{C}$.

From these studies $[76,77]$, it is evident that the D. melanogaster $d C K 2 \alpha$ orthologue can rescue wild type growth in S. cerevisiae mutants, and the complementation assays of four D. melanogaster alleles were temperature dependent. The $d C K 2 \alpha$ A177T and D212N transgenes produced the most robust temperature sensitive growth phenotypes in yeast. In particular, the D212N mutation is of interest as this amino acid residue is close to the CK2 $\alpha$ active site and is thought to play an important structural role in stabilizing the catalytic subunit. It appears likely that this mutation could destabilize the protein structure at high 
temperatures, causing temperature sensitivity $[77,138]$. Whilst these $d C K 2 \alpha$ mutations (Table 2) have not been assessed in D. melanogaster, the protein is required for cellular function and growth. Thus, the $d C K 2 \alpha$ A177T and D212N temperature sensitive mutations appear promising temperature sensitive candidates for establishing GSSs.

\section{What's Still to Come-Efficient Translocation Methods}

Generating GSSs for SIT requires a chromosomal translocation (or insertions) to a sex chromosome, or sex determining chromosomal region. Translocation of a wild type allele to the male determining $\mathrm{Y}$ chromosome will render males resistant to the effects of recessive temperature sensitive alleles, while translocation of a dominant allele, such as $N^{60 g 11}$ or others [139], to the female specific W chromosome will create restrictive phenotypes for species with female heterogametic sex chromosomes. Inducing translocations through radiation is a random process and screening for genetically stable translocation lines that do not impact insect viability is time-consuming and labour-intensive [26]. The structure of the Y-autosome translocation heavily impacts the stability and productivity of the GSS through the segregation of chromosomes during male meiosis and the ability for recombination to occur in males [26]. Karyotypes of genetically unbalanced offspring, caused by chromosomal deletions or triplications, leads to lethality $[26,140]$ and the stability of a GSS is threatened by rare male genetic recombination events either between the translocated wild type chromosome and the free autosome carrying mutant alleles [26,38]. In the case of Medfly VIENNA-8 ${ }^{\text {D53 }}$ GSS, chromosomal inversions have improved strain stability through reducing recombination events at the tsl locus [36], and filter rearing systems (FRS) have helped maintain colony health and provide a system for monitoring and removal of aberrant phenotypes that may otherwise accumulate during mass-rearing [141].

The emergence of CRISPR/Cas9 genome editing system could potentially be used to induce specific Y-autosome translocations in insects. The induction of several DNA doublestrand breaks simultaneously can lead to complex rearrangements in a genome by joining unrelated break ends by nonhomologous end-joining (NHEJ), thus, double-strand breaks on two distinct chromosomes can lead to reciprocal translocations. Chromosome translocations have been successfully achieved via CRISPR/Cas9 in various cell lines [142-144] and model organisms Caenorhabditis elegans [145], D. melanogaster [146] and Arabidopsis thaliana [147]. Establishing insect strains with CRISPR/Cas9 site induced translocations is thought to have potential beyond these model systems, provided adequate reference genome sequences are available to aid with experimental design [146,148]. Whether developed with CRISPR/Cas9 or classical approaches, chromosomal translocations can be stabilized with inversions to minimize unwanted recombination events. However, inversions can impact strain productivity when recombination occurs through the creating imbalanced gametes which are unable to develop [30], representing yet another challenge for maintaining stable GSS colonies for SIT.

Recombination can create unwanted genotypes among GSSs, and phenotypic markers tightly linked with temperature sensitive lethal mutations will have important roles for ongoing maintenance of mass-reared colonies. The white pupae locus has facilitated this role in Medfly strain variants VIENNA-7 and VIENNA-8, as it is tightly linked with the (currently unknown) embryonic lethal temperature sensitive mutation used to selectively remove females. Creating GSS based on known D. melanogaster temperature sensitive mutations will similarly benefit from tightly linked phenotypic markers. Strategies could potentially involve introducing transgenic fluorescent marker genes to the Y-autosome translocation chromosome, or creating mutations with visible phenotypes in genes linked with the temperature sensitive mutation. Quality assessment of strain fitness, before and after translocation experiments, will be required.

\section{Concluding Remarks}

The use of male-only releases in SIT programs minimizes health (in the case of disease vector species) and economic risks (applicable for both agriculture and disease vector 
pests) and increases cost efficiency (cost of mass-rearing and increased field performance of sterile males). A temperature sensitive lethal mutation generated by random mutagenesis has been the key to success for the Medfly GSS, but strain development and optimisation has taken considerable time. The specific tsl mutation currently remains unknown, yet once identified, it may be possible to replicate the same genetic alteration in other species using CRISPR/Cas9 genome editing to generate male selecting strains for SIT. Here we highlighted seven D. melanogaster genes, shibire, Notch, RpII215, pale, transformer-2, Dsor1 and $C K 2 \alpha$, which have potential to act as temperature sensitive embryonic lethal genes if parallel mutations are introduced into the genomes of other insect species. Mutations in these seven genes largely fulfil the key criteria for generating a GSS: (i) they are recessive, (ii) they result in lethality at early development stages at restricted temperature and (iii) they are viable at normal rearing temperatures. Precise nucleotide substitution using CRISPR/Cas9 gene editing technology, will allow for the introduction of specific point mutations into insect genomes and opportunities to determine their suitability as GSS tsl candidates. About $75 \%$ of disease-related genes in humans $[149,150]$ have functional orthologs in D. melanogaster. This statistic provides optimism that Drosophila embryonic temperature sensitive lethal alleles will produce the same conserved phenotype if corresponding mutations are created in other insects.

Supplementary Materials: The following are available online at https://www.mdpi.com/2075 -4450/12/3/243/s1. Supplementary Methods S1. Materials and Methods describing Drosophila husbandry and stock maintenance.

Author Contributions: Conceptualization, S.W.B.; methodology, A.C. and T.N.M.N.; data curation, S.W.B., A.C. and T.N.M.N.; writing—original draft preparation, T.N.M.N., A.C. and S.W.B.; writingreview and editing, T.N.M.N., A.C. and S.W.B.; funding acquisition, S.W.B. and A.C. All authors have read and agreed to the published version of the manuscript.

Funding: This research was funded by the Hermon Slade Foundation grant number HSF 18-6. A.C. was funded by Horticulture Innovation Australia grant numbers MT13059 and FF18002, with research and development levy funds from the vegetable, apple and pear, citrus, strawberry, table grape, cherry and summerfruit industries, with co-investment from South Australian Research and Development Institute (SARDI) and Primary Industries and Regions South Australia (PIRSA).

Data Availability Statement: Methods describing data generation and analysis are available in the file Supplementary Methods S1.

Acknowledgments: We thank Rob Saint (Flinders University) for useful discussions regarding Drosophila developmental genetics and Robert Richards (University of Adelaide) for access to a Drosophila insectary. The study has benefitted from discussions at International Atomic Energy Agency funded meetings for the Coordinated Research Project "Generic approach for the development of genetic sexing strains for SIT applications".

Conflicts of Interest: The authors declare no conflict of interest.

\section{References}

1. Robinson, A.S. Genetic Basis of the Sterile Insect Technique. In Sterile Insect Technique: Principles and Practice in Area-Wide Integrated Pest Management; Dyck, V.A., Hendrichs, J., Robinson, A.S., Eds.; Springer: Dordrecht, The Netherlands, 2005; pp. 95-114. [CrossRef]

2. Klassen, W. Area-Wide Integrated Pest Management and the Sterile Insect Technique. In Sterile Insect Technique: Principles and Practice in Area-Wide Integrated Pest Management; Dyck, V.A., Hendrichs, J., Robinson, A.S., Eds.; Springer: Dordrecht, The Netherlands, 2005; pp. 39-68.

3. Knipling, E. Possibilities of insect control or eradication through use of sexually sterile males. J. Econ. Entomol. 1955, 48, 459-462. [CrossRef]

4. Beketov, M.A.; Kefford, B.J.; Schäfer, R.B.; Liess, M. Pesticides reduce regional biodiversity of stream invertebrates. Proc. Natl. Acad. Sci. USA 2013, 110, 11039-11043. [CrossRef]

5. Nicolopoulou-Stamati, P.; Maipas, S.; Kotampasi, C.; Stamatis, P.; Hens, L. Chemical pesticides and human health: The urgent need for a new concept in agriculture. Front. Public Health 2016, 4, 148. [CrossRef]

6. Wyss, J.H. Screwworm Eradication in the Americas. Ann. N. Y. Acad. Sci. 2000, 916, 186-193. [CrossRef] 
7. $\quad$ Enkerlin, W.; Gutiérrez-Ruelas, J.M.; Cortes, A.V.; Roldan, E.C.; Midgarden, D.; Lira, E.; López, J.L.Z.; Hendrichs, J.; Liedo, P.; Arriaga, F.J.T. Area Freedom in Mexico from Mediterranean Fruit Fly (Diptera: Tephritidae): A Review of Over 30 Years of a Successful Containment Program Using an Integrated Area-Wide SIT Approach. Fla. Entomol. 2015, 98, 665-681. [CrossRef]

8. Marec, F.; Vreysen, M.J.B. Advances and Challenges of Using the Sterile Insect Technique for the Management of Pest Lepidoptera. Insects 2019, 10, 371. [CrossRef]

9. Bourtzis, K.; Lees, R.S.; Hendrichs, J.; Vreysen, M.J.B. More than one rabbit out of the hat: Radiation, transgenic and symbiontbased approaches for sustainable management of mosquito and tsetse fly populations. Acta Trop. 2016, 157, 115-130. [CrossRef]

10. Lees, R.S.; Gilles, J.R.L.; Hendrichs, J.; Vreysen, M.J.B.; Bourtzis, K. Back to the future: The sterile insect technique against mosquito disease vectors. Curr. Opin. Insect Sci. 2015, 10, 156-162. [CrossRef] [PubMed]

11. Sassu, F.; Nikolouli, K.; Caravantes, S.; Taret, G.; Pereira, R.; Vreysen, M.J.B.; Stauffer, C.; Caceres, C. Mass-Rearing of Drosophila suzukii for Sterile Insect Technique Application: Evaluation of Two Oviposition Systems. Insects 2019, 10, 448. [CrossRef]

12. Suckling, D.M.; Conlong, D.E.; Carpenter, J.E.; Bloem, K.A.; Rendon, P.; Vreysen, M.J.B. Global range expansion of pest Lepidoptera requires socially acceptable solutions. Biol. Invasions 2017, 19, 1107-1119. [CrossRef]

13. Parker, A.G. Mass-Rearing for Sterile Insect Release. In Sterile Insect Technique: Principles and Practice in Area-Wide Integrated Pest Management; Dyck, V.A., Hendrichs, J., Robinson, A.S., Eds.; Springer: Dordrecht, The Netherlands, 2005; pp. 209-232. [CrossRef]

14. Cayol, J.P.; Causse, R.; Louis, C.; Barthes, J. Medfly Ceratitis capitata Wiedemann (Dipt., Trypetidae) as a rot vector in laboratory conditions. J. Appl. Entomol. 1994, 117, 338-343. [CrossRef]

15. McInnis, D.O.; Tam, S.; Grace, C.; Miyashita, D. Population suppression and sterility rates induced by variable sex ratio, Sterile Insect Releases of Ceratitis capitata (Diptera: Tephritidae) in Hawaii. Ann. Entomol. Soc. Am. 1994, 87, 231-240. [CrossRef]

16. Rendón, P.; McInnis, D.; Lance, D.; Stewart, J. Medfly (Diptera:Tephritidae) Genetic Sexing: Large-scale field comparison of males-only and bisexual sterile fly releases in Guatemala. J. Econ. Entomol. 2004, 97, 1547-1553. [CrossRef]

17. Caceres, C. Mass rearing of temperature sensitive genetic sexing strains in the Mediterranean fruit fly (Ceratitis capitata). Genetica 2002, 116, 107-116. [CrossRef] [PubMed]

18. Robinson, A.S. Genetic Sexing Strains in Medfly, Ceratitis Capitata, Sterile Insect Technique Programmes. Genetica 2002, 116, 5-13. [CrossRef] [PubMed]

19. Bakri, A.; Mehta, K.; Lance, D.; Dyck, V.; Hendrichs, J.; Robinson, A. Sterilizing Insects with Ionizing Radiation. In Sterile Insect Technique: Principles and Practice in Area-Wide Integrated Pest Management; Dyck, V.A., Hendrichs, J., Robinson, A.S., Eds.; Springer: Dordrecht, The Netherlands, 2005; pp. 233-268. [CrossRef]

20. Bushland, R.C.; Hopkins, D.E. Experiments with Screw-Worm Flies Sterilized by X-Rays. J. Econ. Entomol. 1951, 44, 725-731. [CrossRef]

21. Bushland, R.C. Male sterilization for the control of insects. In Advances in Pest Control Research; Metcalf, R.L., Ed.; Interscience Publishers: New York, NY, USA, 1960; pp. 1-25.

22. Papathanos, P.A.; Bourtzis, K.; Tripet, F.; Bossin, H.; Virginio, J.F.; Capurro, M.L.; Pedrosa, M.C.; Guindo, A.; Sylla, L.; Coulibaly, M.B.; et al. A perspective on the need and current status of efficient sex separation methods for mosquito genetic control. Parasites Vectors 2018, 11, 654. [CrossRef]

23. Zheng, X.; Zhang, D.; Li, Y.; Yang, C.; Wu, Y.; Liang, X.; Liang, Y.; Pan, X.; Hu, L.; Sun, Q.; et al. Incompatible and sterile insect techniques combined eliminate mosquitoes. Nature 2019, 572, 56-61. [CrossRef] [PubMed]

24. Bellini, R.; Medici, A.; Puggioli, A.; Balestrino, F.; Carrieri, M. Pilot Field Trials With Aedes albopictus Irradiated Sterile Males in Italian Urban Areas. J. Med. Entomol. 2013, 50, 317-325. [CrossRef] [PubMed]

25. Seck, M.T.; Pagabeleguem, S.; Bassene, M.D.; Fall, A.G.; Diouf, T.A.R.; Sall, B.; Vreysen, M.J.B.; Rayaissé, J.-B.; Takac, P.; Sidibé, I.; et al. Quality of Sterile Male Tsetse after Long Distance Transport as Chilled, Irradiated Pupae. PLoS Negl. Trop. Dis. 2015, 9, e0004229. [CrossRef]

26. Franz, G. Genetic Sexing Strains in Mediterranean Fruit Fly, an Example for Other Species Amenable to Large-Scale Rearing for the Sterile Insect Technique. In Sterile Insect Technique: Principles and Practice in Area-Wide Integrated Pest Management; Dyck, V.A., Hendrichs, J., Robinson, A.S., Eds.; Springer: Dordrecht, The Netherlands, 2005; pp. 427-451. [CrossRef]

27. McCombs, S.D.; Saul, S.H. Linkage Analysis of Five New Genetic Markers of the Oriental Fruit Fly, Bactrocera dorsalis (Diptera: Tephritidae). J. Hered. 1992, 83, 199-203. [CrossRef] [PubMed]

28. McInnis, D.O.; Tam, S.; Lim, R.; Komatsu, J.; Kurashima, R.; Albrecht, C. Development of a Pupal Color-Based Genetic Sexing Strain of the Melon Fly, Bactrocera cucurbitae (Coquillett) (Diptera: Tephritidae). Ann. Entomol. Soc. Am. 2004, 97, 1026-1033. [CrossRef]

29. Zepeda-Cisneros, C.S.; Meza-Hernandez, J.S.; Garcia-Martinez, V.; Ibanez-Palacios, J.; Zacharopoulou, A.; Franz, G. Development, genetic and cytogenetic analyses of genetic sexing strains of the Mexican fruit fly, Anastrepha ludens Loew (Diptera: Tephritidae). BMC Genet. 2014, 15, S1. [CrossRef] [PubMed]

30. Augustinos, A.A.; Misbah-ul-Haq, M.; Carvalho, D.O.; de la Fuente, L.D.; Koskinioti, P.; Bourtzis, K. Irradiation induced inversions suppress recombination between the M locus and morphological markers in Aedes aegypti. BMC Genet. 2020, $21,142$. [CrossRef]

31. Koskinioti, P.; Augustinos, A.A.; Carvalho, D.O.; Misbah-ul-Haq, M.; Pillwax, G.; de la Fuente, L.D.; Salvador-Herranz, G.; Herrero, R.A.; Bourtzis, K. Genetic sexing strains for the population suppression of the mosquito vector Aedes aegypti. Philos. Trans. R. Soc. B Biol. Sci. 2021, 376, 20190808. [CrossRef] 
32. Rössler, Y. The Genetics of the Mediterranean Fruit Fly: A “White Pupae” Mutant. Ann. Entomol. Soc. Am. 1979, 72, 583-585. [CrossRef]

33. Caceres, C.; Cayol, J.-P.; Enkerlin, W.R.; Franz, G.; Hendrichs, J.; Robinson, A.S. Comparison of Mediterranean fruit fly (Ceratitis capitata) (Tephritidae) bisexual and genetic sexing strains: Development, evaluation and economics. In Proceedings of the 6th International Symposium on Fruit Flies of Economic Importance, Stellenbosch, South Africa, 6-10 May 2002 ; pp. 367-381.

34. Franz, G.; Gencheva, E.; Kerremans, P. Improved stability of genetic sex-separation strains for the Mediterranean fruit fly, Ceratitis capitata. Genome 1994, 37, 72-82. [CrossRef]

35. Franz, G. Development and application of genetic sexing systems for the Mediterranean fruit fly based on a temperature sensitive lethal. In Fruit Fly Pest, A World Assessment of Their Biology and Management; McPheron, B.A., Steck, G.J., Eds.; St. Lucia Press: Miami, FL, USA, 1996; pp. 185-191.

36. Augustinos, A.A.; Targovska, A.; Cancio-Martinez, E.; Schorn, E.; Franz, G.; Cáceres, C.; Zacharopoulou, A.; Bourtzis, K. Ceratitis capitata genetic sexing strains: Laboratory evaluation of strains from mass-rearing facilities worldwide. Entomol. Exp. Appl. 2017, 164, 305-317. [CrossRef]

37. Kerremans, P.; Franz, G. Isolation and cytogenetic analyses of genetic sexing strains for the medfly, Ceratitis capitata. Theor. Appl. Genet. 1995, 91, 255-261. [CrossRef] [PubMed]

38. Franz, G. Recombination Between Homologous Autosomes in Medfly (Ceratitis Capitata) Males: Type-1 Recombination and the Implications for the Stability of Genetic Sexing Strains. Genetica 2002, 116, 73-84. [CrossRef]

39. Sim, S.B.; Ruiz-Arce, R.; Barr, N.B.; Geib, S.M. A New Diagnostic Resource for Ceratitis capitata Strain Identification Based on QTL Mapping. G3 Genes Genomes Genet. 2017, 7, 3637-3647. [CrossRef] [PubMed]

40. Ward, C.M.; Aumann, R.A.; Whitehead, M.A.; Nikolouli, K.; Leveque, G.; Gouvi, G.; Fung, E.; Reiling, S.J.; Djambazian, H.; Hughes, M.A.; et al. White pupae phenotype of tephritids is caused by parallel mutations of a MFS transporter. Nat. Commun. 2021, 12, 491. [CrossRef] [PubMed]

41. Aumann, R.A.; Häcker, I.; Schetelig, M.F. Female-to-male sex conversion in Ceratitis capitata by CRISPR/Cas9 HDR-induced point mutations in the sex determination gene transformer-2. Sci. Rep. 2020, 10, 18611. [CrossRef] [PubMed]

42. Choo, A.; Fung, E.; Chen, I.Y.; Saint, R.; Crisp, P.; Baxter, S.W. Precise single base substitution in the shibire gene by CRISPR/Cas9mediated homology directed repair in Bactrocera tryoni. BMC Genet. 2020, 21, 127. [CrossRef] [PubMed]

43. Li, J.; Handler, A.M. Temperature-dependent sex-reversal by a transformer-2 gene-edited mutation in the spotted wing drosophila, Drosophila suzukii. Sci. Rep. 2017, 7, 12363. [CrossRef] [PubMed]

44. Robinson, A.S. Mutations and their use in insect control. Mutat. Res. 2002, 511, 113-132. [CrossRef]

45. Heinrich, J.C.; Scott, M.J. A repressible female-specific lethal genetic system for making transgenic insect strains suitable for a sterile-release program. Proc. Natl. Acad. Sci. USA 2000, 97, 8229-8232. [CrossRef]

46. Horn, C.; Wimmer, E.A. A transgene-based, embryo-specific lethality system for insect pest management. Nat. Biotechnol. 2003, 21, 64-70. [CrossRef]

47. Thomas, D.D.; Donnelly, C.A.; Wood, R.J.; Alphey, L.S. Insect Population Control Using a Dominant, Repressible, Lethal Genetic System. Science 2000, 287, 2474-2476. [CrossRef]

48. Ogaugwu, C.E.; Schetelig, M.F.; Wimmer, E.A. Transgenic sexing system for Ceratitis capitata (Diptera: Tephritidae) based on female-specific embryonic lethality. Insect Biochem. Mol. Biol. 2013, 43, 1-8. [CrossRef]

49. Schetelig, M.F.; Handler, A.M. A transgenic embryonic sexing system for Anastrepha suspensa (Diptera: Tephritidae). Insect Biochem. Mol. Biol. 2012, 42, 790-795. [CrossRef] [PubMed]

50. Yan, Y.; Scott, M.J. A transgenic embryonic sexing system for the Australian sheep blow fly Lucilia cuprina. Sci. Rep. 2015, 5, 16090. [CrossRef] [PubMed]

51. Hoang, K.P.; Teo, T.M.; Ho, T.X.; Le, V.S. Mechanisms of sex determination and transmission ratio distortion in Aedes aegypti. Parasites Vectors 2016, 9, 49. [CrossRef] [PubMed]

52. Galizi, R.; Doyle, L.A.; Menichelli, M.; Bernardini, F.; Deredec, A.; Burt, A.; Stoddard, B.L.; Windbichler, N.; Crisanti, A. A synthetic sex ratio distortion system for the control of the human malaria mosquito. Nat. Commun. 2014, 5, 3977. [CrossRef]

53. Bernardini, F.; Galizi, R.; Menichelli, M.; Papathanos, P.-A.; Dritsou, V.; Marois, E.; Crisanti, A.; Windbichler, N. Site-specific genetic engineering of the Anopheles gambiae Y chromosome. Proc. Natl. Acad. Sci. USA 2014, 111, 7600. [CrossRef]

54. Catteruccia, F.; Benton, J.P.; Crisanti, A. An Anopheles transgenic sexing strain for vector control. Nat. Biotechnol. 2005, 23, 1414-1417. [CrossRef]

55. Condon, K.C.; Condon, G.C.; Dafa'alla, T.H.; Fu, G.; Phillips, C.E.; Jin, L.; Gong, P.; Alphey, L. Genetic sexing through the use of Y-linked transgenes. Insect Biochem. Mol. Biol. 2007, 37, 1168-1176. [CrossRef] [PubMed]

56. Meza, J.S.; Schetelig, M.F.; Zepeda-Cisneros, C.S.; Handler, A.M. Male-specific Y-linked transgene markers to enhance biologicallybased control of the Mexican fruit fly, Anastrepha ludens (Diptera: Tephritidae). BMC Genet. 2014, 15, S4. [CrossRef] [PubMed]

57. Schetelig, M.F.; Handler, A.M. Y-linked markers for improved population control of the tephritid fruit fly pest, Anastrepha suspensa. Adv. Biochem. Eng. Biotechnol. 2013, 136, 123-133. [CrossRef]

58. Yan, Y.; Scott, M.J. Building a transgenic sexing strain for genetic control of the Australian sheep blow fly Lucilia cuprina using two lethal effectors. BMC Genom. Data 2020, 21, 141. [CrossRef]

59. Fu, G.; Lees, R.S.; Nimmo, D.; Aw, D.; Jin, L.; Gray, P.; Berendonk, T.U.; White-Cooper, H.; Scaife, S.; Kim Phuc, H.; et al. Female-specific flightless phenotype for mosquito control. Proc. Natl. Acad. Sci. USA 2010, 107, 4550-4554. [CrossRef] [PubMed] 
60. Panjwani, A.; Wilson, A. What Is Stopping the Use of Genetically Modified Insects for Disease Control? PLoS Pathog. 2016, 12, e1005830. [CrossRef] [PubMed]

61. Das, S.R.; Maselko, M.; Upadhyay, A.; Smanski, M.J. Genetic engineering of sex chromosomes for batch cultivation of nontransgenic, sex-sorted males. PLoS Genet. 2020, 16, e1009180. [CrossRef] [PubMed]

62. Sahara, K.; Yoshido, A.; Traut, W. Sex chromosome evolution in moths and butterflies. Chromosome Res. 2012, 20, 83-94. [CrossRef] [PubMed]

63. Marec, F.; Neven, L.G.; Robinson, A.S.; Vreysen, M.; Goldsmith, M.R.; Nagaraju, J.; Franz, G. Development of Genetic Sexing Strains in Lepidoptera: From Traditional to Transgenic Approaches. J. Econ. Entomol. 2005, 98, 248-259. [CrossRef]

64. Ma, S.; Wang, X.; Fei, J.; Liu, Y.; Duan, J.; Wang, F.; Xu, H.; Zhao, P.; Xia, Q. Genetic marking of sex using a W chromosome-linked transgene. Insect. Biochem. Mol. Biol. 2013, 43, 1079-1086. [CrossRef] [PubMed]

65. Tamura, T.; Thibert, C.; Royer, C.; Kanda, T.; Abraham, E.; Kamba, M.; Komoto, N.; Thomas, J.L.; Mauchamp, B.; Chavancy, G.; et al. Germline transformation of the silkworm Bombyx mori L. using a piggyBac transposon-derived vector. Nat. Biotechnol. 2000, 18, 81-84. [CrossRef] [PubMed]

66. Marec, F.; Neven, L.G.; Fukova, I. Developing Transgenic Sexing Strains for the Release of Non-Transgenic Sterile Male Codling Moths Cydia pomonella. In Area-Wide Control of Insect Pests; Vreysen, M.J.B., Robinson, A.S., Hendrichs, J., Eds.; Springer: Dordrecht, The Netherland, 2007. [CrossRef]

67. Bai, X.; Zeng, T.; Ni, X.Y.; Su, H.A.; Huang, J.; Ye, G.Y.; Lu, Y.Y.; Qi, Y.X. CRISPR/Cas9-mediated knockout of the eye pigmentation gene white leads to alterations in color of head spots in the oriental fruit fly, Bactrocera dorsalis. Insect Mol. Biol. 2019. [CrossRef] [PubMed]

68. Choo, A.; Crisp, P.; Saint, R.; O'Keefe, L.V.; Baxter, S.W. CRISPR/Cas9-mediated mutagenesis of the white gene in the tephritid pest Bactrocera tryoni. J. Appl. Entomol. 2018, 142, 52-58. [CrossRef]

69. Kistler, K.E.; Vosshall, L.B.; Matthews, B.J. Genome engineering with CRISPR-Cas9 in the mosquito Aedes aegypti. Cell. Rep. 2015, 11, 51-60. [CrossRef] [PubMed]

70. Li, M.; Akbari, O.S.; White, B.J. Highly Efficient Site-Specific Mutagenesis in Malaria Mosquitoes Using CRISPR. G3 Genes Genomes Genet. 2018, 8, 653-658. [CrossRef] [PubMed]

71. Paulo, D.F.; Williamson, M.E.; Arp, A.P.; Li, F.; Sagel, A.; Skoda, S.R.; Sanchez-Gallego, J.; Vasquez, M.; Quintero, G.; Perez de Leon, A.A.; et al. Specific Gene Disruption in the Major Livestock Pests Cochliomyia hominivorax and Lucilia cuprina Using CRISPR/Cas9. G3 Genes Genomes Genet. 2019, 9, 3045-3055. [CrossRef] [PubMed]

72. Lewis, E.B.; Bacher, F. Methods of feeding ethyl methane sulphonate (EMS) to Drosophila males. Drosoph. Inf. Serv. 1968, 43,193

73. Suzuki, D.T. Temperature-Sensitive Mutations in Drosophila melanogaster. Science 1970, 170, 695-706. [CrossRef]

74. Suzuki, D.T.; Grigliatti, T.; Williamson, R. Temperature-Sensitive Mutations in Drosophila melanogaster, VII. A Mutation (parats) Causing Reversible Adult Paralysis. Proc. Natl. Acad. Sci. USA 1971, 68, 890. [CrossRef] [PubMed]

75. Grigliatti, T.A.; Hall, L.; Rosenbluth, R.; Suzuki, D.T. Temperature-sensitive mutations in Drosophila melanogaster. Mol. Gen. Genet. 1973, 120, 107-114. [CrossRef] [PubMed]

76. Hanna, D.E.; Rethinaswamy, A.; Glover, C.V. Casein kinase II is required for cell cycle progression during G1 and G2/M in Saccharomyces cerevisiae. J. Biol. Chem. 1995, 270, 25905-25914. [CrossRef]

77. Kuntamalla, P.P.; Kunttas-Tatli, E.; Karandikar, U.; Bishop, C.P.; Bidwai, A.P. Drosophila protein kinase CK2 is rendered temperature-sensitive by mutations of highly conserved residues flanking the activation segment. Mol. Cell. Biochem. 2009, 323, 49-60. [CrossRef] [PubMed]

78. Poodry, C.A.; Hall, L.; Suzuki, D.T. Developmental properties of shibirets1: A pleiotropic mutation affecting larval and adult locomotion and development. Dev. Biol. 1973, 32, 373-386. [CrossRef]

79. Kim, H.J.; Lee, H.J.; Kim, H.; Cho, S.W.; Kim, J.-S. Targeted genome editing in human cells with zinc finger nucleases constructed via modular assembly. Genome Res. 2009, 19, 1279-1288. [CrossRef]

80. Ramaswami, M.; Rao, S.; van der Bliek, A.; Kelly, R.B.; Krishnan, K.S. Genetic Studies on Dynamin Function in Drosophila. J. Neurogenet. 1993, 9, 73-87. [CrossRef] [PubMed]

81. Krishnan, K.S.; Rikhy, R.; Rao, S.; Shivalkar, M.; Mosko, M.; Narayanan, R.; Etter, P.; Estes, P.S.; Ramaswami, M. Nucleoside diphosphate kinase, a source of GTP, is required for dynamin-dependent synaptic vesicle recycling. Neuron 2001, 30, 197-210. [CrossRef]

82. Narayanan, R.; Leonard, M.; Song, B.D.; Schmid, S.L.; Ramaswami, M. An internal GAP domain negatively regulates presynaptic dynamin in vivo: A two-step model for dynamin function. J. Cell. Biol. 2005, 169, 117-126. [CrossRef] [PubMed]

83. Shellenbarger, D.L.; Mohler, J.D. Temperature-sensitive periods and autonomy of pleiotropic effects of 1(1)Nts1, a conditional notch lethal in Drosophila. Dev. Biol. 1978, 62, 432-446. [CrossRef]

84. Ge, X.; Hannan, F.; Xie, Z.; Feng, C.; Tully, T.; Zhou, H.; Xie, Z.; Zhong, Y. Notch signaling in Drosophila long-term memory formation. Proc. Natl. Acad. Sci. USA 2004, 101, 10172-10176. [CrossRef]

85. Portin, P.; Sirén, M. Timing of temperature-sensitive period for lethality of Abruptex mutations of Drosophila melanogaster. Hereditas 1976, 84, 109-116. [CrossRef]

86. Welshons, W.J.; von Halle, E.S. Pseudoallelism at the notch locus in drosophila. Genetics 1962, 47, 743-759. [CrossRef] [PubMed]

87. Foster, G.G. Temperature-sensitive mutations in Drosophila melanogaster: XIII. Temperature-sensitive periods of the lethal and morphological phenotypes of selected combinations of notch-locus mutations. Dev. Biol. 1973, 32, 282-296. [CrossRef] 
88. Fryxell, K.J.; Miller, T.A. Autocidal Biological Control: A General Strategy for Insect Control Based on Genetic Transformation with a Highly Conserved Gene. J. Econ. Entomol. 1995, 88, 1221-1232. [CrossRef]

89. Lyman, D.; Young, M.W. Further evidence for function of the Drosophila Notch protein as a transmembrane receptor. Proc. Natl. Acad. Sci. USA 1993, 90, 10395-10399. [CrossRef]

90. Mortin, M.A.; Kaufman, T.C. Development effects of a temperature-sensitive RNA polymerase II mutation in Drosophila melanogaster. Dev. Biol. 1984, 103, 343-354. [CrossRef]

91. Pendleton, R.G.; Rasheed, A.; Sardina, T.; Tully, T.; Hillman, R. Effects of tyrosine hydroxylase mutants on locomotor activity in Drosophila: A study in functional genomics. Behav. Genet. 2002, 32, 89-94. [CrossRef]

92. Belote, J.M.; Lucchesi, J.C. Control of X chromosome transcription by the maleless gene in Drosophila. Nature 1980, $285,573-575$. [CrossRef]

93. Hsu, J.C.; Perrimon, N. A temperature-sensitive MEK mutation demonstrates the conservation of the signaling pathways activated by receptor tyrosine kinases. Genes Dev. 1994, 8, 2176-2187. [CrossRef] [PubMed]

94. Chen, M.S.; Obar, R.A.; Schroeder, C.C.; Austin, T.W.; Poodry, C.A.; Wadsworth, S.C.; Vallee, R.B. Multiple forms of dynamin are encoded by shibire, a Drosophila gene involved in endocytosis. Nature 1991, 351, 583-586. [CrossRef] [PubMed]

95. van der Bliek, A.M.; Meyerowitz, E.M. Dynamin-like protein encoded by the Drosophila Shibire gene associated with vesicular traffic. Nature 1991, 351, 411-414. [CrossRef] [PubMed]

96. Clark, S.G.; Shurland, D.-L.; Meyerowitz, E.M.; Bargmann, C.I.; van der Bliek, A.M. A dynamin GTPase mutation causes a rapid and reversible temperature-inducible locomotion defect in C.elegans. Proc. Natl. Acad. Sci. USA 1997, 94, 10438-10443. [CrossRef] [PubMed]

97. Damke, H.; Baba, T.; van der Bliek, A.M.; Schmid, S.L. Clathrin-independent pinocytosis is induced in cells overexpressing a temperature-sensitive mutant of dynamin. J. Cell Biol. 1995, 131, 69-80. [CrossRef] [PubMed]

98. Grant, D.; Unadkat, S.; Katzen, A.; Krishnan, K.S.; Ramaswami, M. Probable mechanisms underlying interallelic complementation and temperature-sensitivity of mutations at the shibire locus of Drosophila melanogaster. Genetics 1998, 149, $1019-1030$.

99. Poodry, C.A. Shibire, a neurogenic mutant of Drosophila. Dev. Biol. 1990, 138, 464-472. [CrossRef]

100. Kim, Y.-T.; Wu, C.-F. Allelic Interactions at the Shibire Locus of Drosophila: Effects on Behavior. J. Neurogenet. 1990, 7, 1-14. [CrossRef] [PubMed]

101. Wharton, K.A.; Johansen, K.M.; Xu, T.; Artavanis-Tsakonas, S. Nucleotide sequence from the neurogenic locus Notch implies a gene product that shares homology with proteins containing EGF-like repeats. Cell 1985, 43, 567-581. [CrossRef]

102. Kidd, S.; Kelley, M.R.; Young, M.W. Sequence of the notch locus of Drosophila melanogaster: Relationship of the encoded protein to mammalian clotting and growth factors. Mol. Cell. Biol. 1986, 6, 3094-3108. [CrossRef]

103. Wang, X.; Adam, J.C.; Montell, D. Spatially localized Kuzbanian required for specific activation of Notch during border cell migration. Dev. Biol. 2007, 301, 532-540. [CrossRef]

104. Brennan, C.A.; Moses, K. Determination of Drosophila photoreceptors: Timing is everything. Cell. Mol. Life Sci. CMLS 2000, 57, 195-214. [CrossRef] [PubMed]

105. Gonzalez-Reyes, A.; St Johnston, D. Patterning of the follicle cell epithelium along the anterior-posterior axis during Drosophila oogenesis. Development 1998, 125, 2837-2846. [PubMed]

106. Ward, E.J.; Zhou, X.; Riddiford, L.M.; Berg, C.A.; Ruohola-Baker, H. Border of Notch activity establishes a boundary between the two dorsal appendage tube cell types. Dev. Biol. 2006, 297, 461-470. [CrossRef]

107. Shellenbarger, D.L.; Mohler, J.D. Temperature-sensitive mutations of the notch locus in Drosophila melanogaster. Genetics 1975, 81, 143-162. [CrossRef]

108. de Celis, J.F.; Garcia-Bellido, A. Modifications of the notch function by Abruptex mutations in Drosophila melanogaster. Genetics 1994, 136, 183-194. [PubMed]

109. Xu, T.; Caron, L.A.; Fehon, R.G.; Artavanis-Tsakonas, S. The involvement of the Notch locus in Drosophila oogenesis. Development 1992, 115, 913.

110. Kelley, M.R.; Kidd, S.; Deutsch, W.A.; Young, M.W. Mutations altering the structure of epidermal growth factor-like coding sequences at the Drosophila Notch locus. Cell 1987, 51, 539-548. [CrossRef]

111. Gordon, W.R.; Arnett, K.L.; Blacklow, S.C. The molecular logic of Notch signaling-A structural and biochemical perspective. J. Cell Sci. 2008, 121, 3109-3119. [CrossRef] [PubMed]

112. Foster, G.G.; Suzuki, D.T. Temperature-sensitive mutations in Drosophila melanogaster. IV. A mutation affecting eye facet arrangement in a polarized manner. Proc. Natl. Acad. Sci. USA 1970, 67, 738-745. [CrossRef] [PubMed]

113. Mortin, M.A.; Kaufman, T.C. Developmental genetics of a temperature sensitive RNA polymerase II mutation in Drosophila melanogaster. Mol. Gen. Genet. 1982, 187, 120-125. [CrossRef]

114. Ingles, C.J.; Biggs, J.; Wong, J.K.; Weeks, J.R.; Greenleaf, A.L. Identification of a structural gene for a RNA polymerase II polypeptide in Drosophila melanogaster and mammalian species. Proc. Natl. Acad. Sci. USA 1983, 80, 3396-3400. [CrossRef]

115. Krasnoselskaya, I.; Huang, J.; Jones, T.; Dezan, C.; Mortin, M.A. Selection and analysis of rare second-site suppressors of Drosophila RNA polymerase II mutations. Mol. Gen. Genet. 1998, 258, 457-465. [CrossRef]

116. Severinov, K.; Mustaev, A.; Kukarin, A.; Muzzin, O.; Bass, I.; Darst, S.A.; Goldfarb, A. Structural Modules of the Large Subunits of RNA Polymerase: Introducing archaebacterial and chloroplast split sites in the $\beta$ and $\beta^{\prime}$ subunits of Escherichia coli RNA polymerase. J. Biol. Chem. 1996, 271, 27969-27974. [CrossRef] [PubMed] 
117. Cramer, P.; Bushnell, D.A.; Kornberg, R.D. Structural Basis of Transcription: RNA Polymerase II at 2.8 Ångstrom Resolution. Science 2001, 292, 1863. [CrossRef]

118. Neckameyer, W.S.; White, K. Drosophila tyrosine hydroxylase is encoded by the pale locus. J. Neurogenet. 1993, 8, 189-199. [CrossRef]

119. Swinderen, B.V.; Andretic, R. Dopamine in Drosophila: Setting arousal thresholds in a miniature brain. Proc. R Soc. B Biol. Sci. 2011, 278, 906-913. [CrossRef] [PubMed]

120. Liu, T.; Dartevelle, L.; Yuan, C.; Wei, H.; Wang, Y.; Ferveur, J.-F.; Guo, A. Reduction of Dopamine Level Enhances the Attractiveness of Male Drosophila to Other Males. PLoS ONE 2009, 4, e4574. [CrossRef] [PubMed]

121. Jürgens, G.; Wieschaus, E.; Nüsslein-Volhard, C.; Kluding, H. Mutations affecting the pattern of the larval cuticle in Drosophila melanogaster: II. Zygotic loci on the third chromosome. Wilehm Roux Arch. Dev. Biol. 1984, 193, 283-295. [CrossRef]

122. Bachtrog, D.; Mank, J.E.; Peichel, C.L.; Kirkpatrick, M.; Otto, S.P.; Ashman, T.-L.; Hahn, M.W.; Kitano, J.; Mayrose, I.; Ming, R.; et al. Sex Determination: Why So Many Ways of Doing It? PLoS Biol. 2014, 12, e1001899. [CrossRef]

123. Tian, M.; Maniatis, T. A splicing enhancer complex controls alternative splicing of doublesex pre-mRNA. Cell 1993, 74, 105-114 [CrossRef]

124. Amrein, H.; Gorman, M.; Nöthiger, R. The sex-determining gene tra-2 of Drosophila encodes a putative RNA binding protein. Cell 1988, 55, 1025-1035. [CrossRef]

125. Hedley, M.L.; Maniatis, T. Sex-specific splicing and polyadenylation of $d s x$ pre-mRNA requires a sequence that binds specifically to tra-2 protein in vitro. Cell 1991, 65, 579-586. [CrossRef]

126. Hoshijima, K.; Inoue, K.; Higuchi, I.; Sakamoto, H.; Shimura, Y. Control of doublesex alternative splicing by transformer and transformer-2 in Drosophila. Science 1991, 252, 833. [CrossRef]

127. Liu, G.; Wu, Q.; Li, J.; Zhang, G.; Wan, F. RNAi-Mediated Knock-Down of transformer and transformer 2 to Generate Male-Only Progeny in the Oriental Fruit Fly, Bactrocera dorsalis (Hendel). PLoS ONE 2015, 10, e0128892. [CrossRef]

128. Thongsaiklaing, T.; Nipitwattanaphon, M.; Ngernsiri, L. The transformer2 gene of the pumpkin fruit fly, Bactrocera tau (Walker), functions in sex determination, male fertility and testis development. Insect Mol. Biol. 2018. [CrossRef] [PubMed]

129. Salvemini, M.; Robertson, M.; Aronson, B.; Atkinson, P.; Polito, C.; Saccone, G. Ceratitis capitata transformer- 2 gene is required to establish and maintain the auto-regulation of Cctra, the master gene for female sex determination. Int. J. Dev. Biol. 2009, 53, 109-120. [CrossRef]

130. Schetelig, M.F.; Milano, A.; Saccone, G.; Handler, A.M. Male only progeny in Anastrepha suspensa by RNAi-induced sex reversion of chromosomal females. Insect Biochem. Mol. Biol. 2012, 42, 51-57. [CrossRef]

131. Belote, J.M.; Baker, B.S. Sex determination in Drosophila melanogaster: Analysis of transformer-2, a sex-transforming locus. Proc. Natl. Acad. Sci. USA 1982, 79, 1568. [CrossRef]

132. Belote, J.M.; Lucchesi, J.C. Male-specific lethal mutations of Drosophila melanogaster. Genetics 1980, 96, 165-186. [PubMed]

133. Amrein, H.; Maniatis, T.; Nothiger, R. Alternatively spliced transcripts of the sex determinaing gene tra-2 of Drosophila encode functional proteins of different size. EMBO 1990, 9, 3619-3629. [CrossRef]

134. Belote, J.M.; Handler, A.M.; Wolfner, M.F.; Livak, K.J.; Baker, B.S. Sex-specific regulation of yolk protein gene expression in Drosophila. Cell 1985, 40, 339-348. [CrossRef]

135. Bandziulis, R.J.; Swanson, M.S.; Dreyfuss, G. RNA-binding proteins as developmental regulators. Genes Dev. 1989, 3, 431-437. [CrossRef]

136. Tsuda, L.; Inoue, Y.H.; Yoo, M.A.; Mizuno, M.; Hata, M.; Lim, Y.M.; Adachi-Yamada, T.; Ryo, H.; Masamune, Y.; Nishida, Y. A protein kinase similar to MAP kinase activator acts downstream of the raf kinase in Drosophila. Cell 1993, 72, 407-414. [CrossRef]

137. Carr, A.M.; MacNeill, S.A.; Hayles, J.; Nurse, P. Molecular cloning and sequence analysis of mutant alleles of the fission yeast cdc2 protein kinase gene: Implications for $\mathrm{cdc}^{+}$protein structure and function. Mol. Gen. Genet. MGG 1989, 218, 41-49. [CrossRef] [PubMed]

138. Bandyopadhyay, M.; Arbet, S.; Bishop, C.P.; Bidwai, A.P. Drosophila protein kinase CK2: Genetics, regulatory complexity and emerging roles during development. Pharmaceuticals 2017, 20, 4. [CrossRef] [PubMed]

139. Nirmala, X.; Zimowska, G.J.; Handler, A.M. Characterization of the proteasomebeta2 subunit gene and its mutant allele in the tephritid fruit fly pest, Anastrepha suspensa. Insect. Mol. Biol. 2009, 18, 333-340. [CrossRef] [PubMed]

140. Zacharopoulou, A.; Augustinos, A.A.; Drosopoulou, E.; Tsoumani, K.T.; Gariou-Papalexiou, A.; Franz, G.; Mathiopoulos, K.D.; Bourtzis, K.; Mavragani-Tsipidou, P. A review of more than 30 years of cytogenetic studies of Tephritidae in support of sterile insect technique and global trade. Entomol. Exp. Appl. 2017, 164, 204-225. [CrossRef]

141. Fisher, K.; Caceres, C. A filter rearing system for mass reared genetic sexing strains of Mediterranean fruit fly (Diptera: Tephritidae). In Area-Wide Control of Fruit Flies and Other Insect Pests Joint Proceedings of the International Conference on Area-Wide Control of Insect Pests and the Fifth International Symposium on Fruit Flies of Economic Importance; Tan, K.-H., Ed.; Penerbit Universiti Sains: Penang, Malaysia, 2000; pp. 543-550.

142. Choi, P.S.; Meyerson, M. Targeted genomic rearrangements using CRISPR/Cas technology. Nat. Commun. 2014, 5, 3728. [CrossRef] [PubMed]

143. Torres, R.; Martin, M.C.; Garcia, A.; Cigudosa, J.C.; Ramirez, J.C.; Rodriguez-Perales, S. Engineering human tumour-associated chromosomal translocations with the RNA-guided CRISPR-Cas9 system. Nat. Commun. 2014, 5, 3964. [CrossRef] [PubMed] 
144. Lagutina, I.V.; Valentine, V.; Picchione, F.; Harwood, F.; Valentine, M.B.; Villarejo-Balcells, B.; Carvajal, J.J.; Grosveld, G.C. Modeling of the human alveolar rhabdomyosarcoma Pax3-Foxo1 chromosome translocation in mouse myoblasts using CRISPR-Cas9 nuclease. PLoS Genet. 2015, 11, e1004951. [CrossRef] [PubMed]

145. Chen, X.; Li, M.; Feng, X.; Guang, S. Targeted Chromosomal Translocations and Essential Gene Knockout Using CRISPR/Cas9 Technology in Caenorhabditis elegans. Genetics 2015, 201, 1295-1306. [CrossRef]

146. Buchman, A.B.; Ivy, T.; Marshall, J.M.; Akbari, O.S.; Hay, B.A. Engineered Reciprocal Chromosome Translocations Drive High Threshold, Reversible Population Replacement in Drosophila. ACS Synthet. Biol. 2018, 7, 1359-1370. [CrossRef] [PubMed]

147. Beying, N.; Schmidt, C.; Pacher, M.; Houben, A.; Puchta, H. CRISPR-Cas9-mediated induction of heritable chromosomal translocations in Arabidopsis. Nat. Plants 2020, 6, 638-645. [CrossRef]

148. Champer, J.; Buchman, A.; Akbari, O.S. Cheating evolution: Engineering gene drives to manipulate the fate of wild populations. Nat. Rev. Genet. 2016, 17, 146-159. [CrossRef]

149. Reiter, L.T.; Potocki, L.; Chien, S.; Gribskov, M.; Bier, E. A systematic analysis of human disease-associated gene sequences in Drosophila melanogaster. Genome Res. 2001, 11, 1114-1125. [CrossRef]

150. Bier, E. Drosophila, the golden bug, emerges as a tool for human genetics. Nat. Rev. Genet. 2005, 6, 9-23. [CrossRef] [PubMed] 